\title{
THE ISOLATION AND CHARACTERIZATION OF A DNA FROM THE CHLOROPLASTS OF PISUM SATIVUM
}

By

ERNEST WILSON

A DISSERTATION PRESENTED TO THE GRADUATE COUNCIL OF THE UNIVERSTTY OF FLORIDA IN PARTLAL FULFILLMENT OF THE REQUIREMENTS FOR THE DEGREE OF DOCTOR OF PHILOSOPHY

UNIVERSITY OF FLORIDA

August, 1966 


\section{ACKNOWLEDGMENTS}

The author wishes to express his sincere appreciation to Dr. S. H. West, his supervisory chairman, for financial assistance and the use of the laboratory facilities. In addition, he would like to thank Mr. J. Brollman and D. Block for certain technical assistance, and Mr. E. B. Wilson for his aid in preparing the manuscript. 
TABLE OF CONTENTS

Page

ACKNOWLEDGMENTS ............ . . .

LIST OF TABLES. . . . . . . . . . . . iv

LIST OF FIGURES . . . . . . . . . . . . . vi

INTRODUCTION. .................. 1

REVIEW OF THE LITERATURE. . . . . . . . . . 3

MATERIAL AND METHODS. . . . . . . . . . 7

Extraction of Nucleic Acids.......... 11

Analytical Procedures........... 18

RESULTS . . . . . . . . . . . . 2 21

Characterization of the DNA Isolated..... 78

Melting Point Determinations . . . . . . 86

DISCUSSION. . . . . . . . . . . 93

SUMMARY . . . . . . . . . . . . 98

BIBLIOGRAPHY. . . . . . . . . . . . 99

BIOGRAPHICAL SKETCH . . . . . . . . 102 


\section{LIST OF TABLES}

Table

Page

1. The Distribution of $260 \mathrm{mu}$ Absorbance in Cold Acid Extracts of Chloroplast Samples Prepared From 20 Gram Samples of Old Leaves; One Group of Plants was Grown for Three Days in the. Light, the Other was Grown in the Dark...

2. The Distribution of Nucleic Acids Isolated From Eight Grams of Pea Leaves in Fractions Prepared During the Isolation of Chloroplasts.

3. The Distribution of Nucleic Acids Among

Fractions Prepared During Chloroplast

Isolation From Ten Grams of Pea Leaves . . . .

4. The uv Absorbancy and DPA Activity of Samples Prepared by Detergent Extraction of Fractions Prepared From Leaves of Flowering Peas . . .

5. The uv Absorbancy and DPA Activity of Detergent Supernatants Prepared From Turnip Greens Leaves. . . . . . . . . . . .

6. The uv Absorbances and DPA Activities of Detergent Supernatants Prepared From Pea Chloroplasts . . . . . . . . . . .

7. The $600 \mathrm{mu}$ Absorbance of DPA Treated Phenol Extract of Detergent Precipitated Chloroplasts Isolated From 21 Grams of Pea Leaves . . . .

8. The Incorporation of $\mathrm{P}^{32}$ Into an Alkaline Hydrolysate of RNAase Treated Nucleic Acids Isolated From Pea Leaves . . . . . . . .

9. The Distribution of uv Absorbing Material in 1.OM NaCl Eluates From a Methylated Albumin Column to Which Samples Prepared From Detergent Extracted Chloroplast and Mitochondrial Fractions Were Added............

10. The Incorporation of $\mathrm{P}^{32}$ Into Alkali Insoluble and Soluble Portions of Detergent Extracted Mitochondrial and Chloroplast Fractions Isolated From Etiolated Pea Leaves Exposed to Iight and Dark .............. 
11. Incorporation of $\mathrm{p}^{32}$ Into the Detergent Precipitates Isolated From the $30,000 \mathrm{X} \mathrm{g}$ Precipitate Prepared From Leaves of Etiolated Pea Plants Exposed to Six Hours of Light or to Darkness... . . . . . . . . . 79

12. The Distribution of Optical Density at $260 \mathrm{mu}$ Due to $\underline{E}$. coli DNA Through a CsCl Gradient. . . 84 


\section{LIST OF FIGURES}

12. A uv absorbance tracing from the eluate of a methylated albumin column of a nucleic acid fraction prepared by phenol extraction of 10 grams of oat leaves grown in.light. . . . .

1b. A uv absorbance tracing from the eluate of a methylated albumin column of a nucleic acid extract prepared using a Brendler teflon pestle homogenizer to break up the cells of oat leaves grown in the light.........

2. A uv absorption tracing from a methylated albumin column of nucleic acid prepared from the chloroplast fraction of oat leaves. . .

3. The distribution of uv absorbance among fractions collected from a methylated albumin column. . . . . . . . . . . . .

4. A uv absorbance tracing from the eluate of a methylated albumin column of a nucleic acid fraction isolated from the chloroplast fraction of mustard green leaves prepared by phenol extraction .. . . . . . . . .

5a. A uv absorbance tracing of an eluate from a methylated albumin column . . . . . . .

5b. A uv absorbance tracing of the other half of

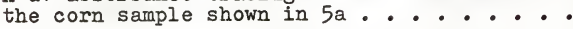

6. The incorporation of $\mathrm{P}^{32}$ into an RNAase resistant nucleic acid isolated from the chloroplast fraction prepared from rootless peanut cuttings . . . . . . . . . . .

7. Incorporation of $\mathrm{P}^{32}$ into an RNAase resistant nucleic acid from the chloroplast fraction of pea tops excised from their roots

8. Incorporation of $\mathrm{P}^{32}$ into an RNAase resistant nucleic acid isolated from the chloroplast fraction prepared from pea plants with intact roots ...... . . . . . . 
9. The incorporation of $\mathrm{P}^{32}$ into an RNAase resistant nucleic acid isolated from the chloroplast fraction prepared from leaves of pea plants excised from roots ......:

10. The incorporation of $\mathrm{P}^{32}$ into an RNAase resistant nucleic acid isolated from the mitochondrial fraction of leaves prepared from excised pea tops . . . . . . . . 5

11. Incorporation of $\mathrm{P}^{32}$ into a RNAase resistant nucleic acid isolated from $30,000 \mathrm{x} \mathrm{g}$ detergent precipitate prepared from chloroplast fraction on pea leaves obtained from excised pea tops .........

12. The incorporation of $\mathrm{P}^{32}$ into RNAase resistant nucleic acid isolated from the $100,000 \mathrm{X} g$ precipitate prepared from the detergent supernatant fraction obtained from the chloroplast fraction of pea leaves from excised tops. . . . . . . . . . .

13. The incorporation of $\mathrm{P}^{32}$ into an RNAase resistant nucleic acid isolated from the supernatant of detergent extracted chloroplast fraction prepared from leaves of excised pea shoots..............

14. The incorporation of $\mathrm{P}^{32}$ into an RNAase resistant nucleic acid isolated from the supernatant fraction of the detergent extracted mitochondrial from leaves of excised pea shoots...........

15. A uv absorbance tracing from a methylated albumin column of a sample of nucleic acid prepared from pea leaves by phenol extraction using a mortar and pestle to break up the pea leaf cells...............

16. The distribution of $0 D 260$ and $P^{32}$ incorporation into nucleic acid samples eluted from a methylated albumin column with a linear gradient of sodium chloride. . . . 
17. The distribution of OD 260 from RNAase treated nucleic acid extract in eluates from a methylated albumin column eluted with a linear sodium chloride gradient.........

18. The effect of DNAase on the elution pattern of a RNAase resistant nucleic acid from a methylated albumin column........ 72

19. A uv absorbance tracing from a methylated albumin column of a detergent supernatant prepared from the 30,000 X $g$ precipitate of an homogenate prepared from light grown and dark grown pea plants........... 82

20. Melting point profiles of pea DNAs . . . . 88

21. Melting point profiles of DNAs prepared from mitochondrial and chloroplast fractions from pea leaves 
INTRODUCTION

The presence of hereditary matierial within the cytoplasmic organelles has been a subject of debate for a long time. The presence of extranuclear Deoxyribose Nucleic Acid (DNA) has been extremely difficult to demonstrate due to the possibility of contamination from the nucleus or from external microbiological sources. Plastids are known to reproduce themselves. Numerous photomicrographs demonstrate this (Green, 1964). Chemical analysis showed the presence of DNA in chloroplast fractions but were open to the same objections as were raised against the reported occurrence of the molecule in the cytoplasm. Recent experiments with algae, particularly with aseptic cultures of the large unicellular alga, Acetabularia, an organism from which the nucleus may be excised, demonstrated that DNA was present in the plastid (Gibor and Izawa, 1963).

The inheritance of plastids and the control of their metabolism are subjects of general interest. The presence of DNA in the chloroplasts of algae raised the question as to whether it was present in the plastids of higher plants. Such a discovery would provide a molecular basis for the reported partial genetic independence of plastids. Any 
further developments in the fleld of chloroplast genetics would require a knowledge of the amount of nuclelc acids produced and the different types made in the plastid.

This work was begun with the hope of discovering DNA in the chloroplasts of higher plants. Since that time several invest1gators, Chun, Vaughan and Rich (1963), K1rk (1963) have reported the occurrence of DNA in plastids of spinach and broad bean. It was attempted to extend the work to the plastids of pea. 


\section{REVIEW OF THE LITERATURE}

It is well known that the nucleus is the site where the major portion of the hereditary material is concentrated. Early in the history of the science of genetics it was suspected that plastids contained a genetic component independent of the nuclear one. Investigations on the inheritance of plastids in variegated and albino plants indicated that this was so even though the nucleus played a very large role in determining the phenotype of the plastid (Granick, 1955). Work using the flagellate, Euglena gracilis, led to the discovery of mutagenic agents specific for chloroplast genes (Gibor and Granick, 1964). The presence of DNA in isolated plastids was often reported in the literature (Chiba and Sugahara, 1957), but these results were always open to the objection that the DNA obtained arose from contamination by nuclear or bacterial particles.

Recent work has overcome these difficulties. Sager (1963) obtained a DNA from the chloroplast fraction of the green alga, Chlamydomonas. The chloroplasts when purified by centrifuging the isolated plastids on a discontinuous sucrose gradient yielded a chloroplast suspension freed from cell wall fragments, whole cells and whole nuclei. The DNAs 
extracted from this purified fraction and those extracted from whole cells were subjected to cesium chloride gradient centrifugation. This technique enabled the investigator to separate different species of DNA with high degree of resolution and at the same time gave information about the base composition of the DNA species. The results of this gradient centrifugation indicated that two DNA species were present, a major one having a buoyant density of 1.728 and a minor band having a buoyant density of 1.702. The minor component is only 6 per cent of the total DNA in the extract of the whole cells, but makes up to 39 per cent of the total DNA isolated from the chloroplast fraction. The minor component was concentrated by procedures which purify the chloroplasts. Hence this minor component was considered to be chloroplast DNA.

Similar results were found using the cells of Euglena gracilis as chloroplast source (Brawerman and Eisenstadt, 1964). A method was developed by which purified chloroplasts were obtained; CsCl density centrifugation was used to achieve the final DNA separation. When a strain of Euglena which had lost the ability to form plastids was used to prepare DNA, the minor component was no longer present (Ray and Hanawatt, 1965).

The green alga, Acetabularia, is uniquely fitted for investigations of this kind. The nucleus of the plant can be removed by mechanical means leaving intact the 
chloroplast complement. A DNA has been 1solated from chloroplasts of enucleate Acetabularia. The DNA content of the chloroplast fraction is $10^{-16} \mathrm{~g}$. per cell (Gibor and Izawa, 1963). Balthus and Brachet (1963) also prepared chloroplast DNA from enucleate Acetabularia cells grown under aseptic conditions. In this case the DNA isolated from the cells could not be due elther to nuclear or bacterial contamination.

Chloroplasts isolated from the leaves of higher plants have been shown to contain DNA. Chun, Vaughan and RIch (1963), using a CsCl gradient, showed the presence of a specific chloroplast DNA isolated from spinach and beets. The amount of DNA in the chloroplasts was about 1 per cent of the total DNA in the cell. Kirk (1963) was able to separate nucle1 from chloroplasts of broad bean in a discontinuous sucrose gradient. The DNA associated with the chloroplast fraction had a different base composition from that associated with the nuclear fraction. Shipp, Kieras and Haselkorn (1965) isolated DNA from tobacco leaf chloroplast. The DNA of the plastids hybridized to the nuclear DNA to the same extent as the completely unrelated E. coli DNA hybridized to it.

Autoradiographic techniques have also been used to show the presence of DNA in the plastid. Wollgiehn and Mothes (1964) showed that tritiated thymidine was incorporated 
into the chloroplasts of Nicotiana rustica cuttings. If DNAase was added to the leaves before fixation, no silver grains appeared under the plastids. No such effect was observed with RNAase treatment. Plastids in older leaves incorporated significantly less radioactivity than did those in younger leaves: Tritlated thymidine has also been shown to be incorporated into the plastids of Spirogyra (Stocking and Gifford, 1959), and Euglena (Sagan, BenShaul, Epstein and Schiff, 1965).

Electron microscopic evidence for DNA in the plastid has been reported by $\mathrm{R} 1 \mathrm{~s}$ and Plaut (1962) for plast1ds of Chlamydomonas. Similar pictures were taken of the chloroplast of Swiss Chard proplastids (Kislev, Swift and Bagorad, cited in Gibor and Granick, 1964). 
MATERIAI AND METHODS

Plant material

Pisum sativum var. Alaska was used in most experiments. The plants were grown for nine to fourteen days in a growth chamber at $80^{\circ} \mathrm{F}$ under 14 hours of light and 10 hours of darkness. Dark grown plants were grown in another growth chamber at $70^{\circ} \mathrm{F}$. In some of the early experiments, oats, mustard greens and peanuts were used as plant material. None of these plants were as satisfactory as pea in either ease of release of plastids from cell or length of time necessary to grow the plant to obtain a sufficient quantity of leaf material. The leaves and the apical tip of the plant were the only portions used as source of plastids. Preparation of isolated chloroplasts

Cell breakage: Several methods were employed. In early experiments an omni-mixer was used. With oat leaves this instrument was necessary to obtain a high degree of cell rupture. The leaves were cut up with a razor blade and placed within the homogenizer together with the isolating medium. The varistat was set at 35 and homogenization proceeded for 3 minutes. A cell homogenizer, based on an adaptation of a standard glass homogenizer suggested by 
Brendler (1951), was utilized to homogenize the leaves of pea, peanut and mustard green. The technique most commonly employed was breakage of the leaf material in a chilled mortar. Even though this technique was less effective than the Brendler technique in homogenization of leaves, it was thought to produce less deleterious effects on the isolated chloroplasts.

At the beginning of the homogenation procedure, the leaf material was added to the chilled mortar and only enough isolation medium to wet the leaves was added. More medium prevents the close contact between mortar and cells which is necessary for this breakage. Walker (1965) observed that the breakup of isolated chloroplasts in aqueous medium is inhibited by sucrose. One gram of solid sucrose was added to the leaves before grinding. No attempt was made to find out the effect of this on the isolated chloroplast. In some cases it was difficult to achieve a high degree of cell breakage. Several different abrasive substances were tried before adsorptive alumina was chosen.

Several kinds of isolating media were tried. Basically all were sucrose media to which various other substances were added because of their supposed ability to protect the plastid from disintegration. A medium suggested by Brawerman and Elsenstadt (1964) was used for the preparation of plastids. The medium consists of $0.25 \underline{\mathrm{M}}$ sucrose, $0.004 \mathrm{M} \mathrm{MgCl} 2$, and $0.001 \mathrm{M}$ mercaptoethanol in $0.01 \mathrm{M}$ Tris $\mathrm{HCl} \mathrm{pH} 7.7$. Another medium 
used was one developed for the stabilization of isolated chloroplasts; the so-called W medium was made up of $0.25 \mathrm{M}$ sucrose, 25 per cent Ficoll (a polymer of sucrose obtained from Pharmacia, Fairlawn, N.J.), 5 per cent dextran, 0.006M mercaptoethanol, 1 per cent bovine serum albumin, and $0.001 \mathrm{M}$ each of $\mathrm{MgCl}_{2}, \mathrm{MnCl}_{2}$, and $\mathrm{CaCl}_{2}$ in $0.01 \mathrm{M}$ Tris $\mathrm{HCl} \mathrm{pH} 7.8$. Purufication of plastids.

The broken material was filtered through two thicknesses of cheesecloth. Any alumina present was removed by a 5-minute centrifugation at $500 \mathrm{x} \mathrm{g}$. Whole chloroplasts, and cell and wall fragments were sedimented by a 10-minute centrifugation at $3,000 \mathrm{Xg}$. The $3,000 \mathrm{Xg}$ sediment was further purified by suspending the material in $15 \mathrm{ml}$. of a 2.0M sucrose solution and floating this on a $2.5 \mathrm{M}$ sucrose solution. This discontinuous gradient was centrifuged at $33,000 \mathrm{Xg}$ for 15 minutes in rotor 25.1 of a Spinco Model L preparative ultracentrifuge. Cell and wall fragments, starch grains and some plastids formed a precipitate at the bottom of the tube. Most chloroplasts accumulated at the interface between the two sucrose solutions. The top layer of sucrose solution, for the most part free of plastids, was removed by means of a syringe. More isolation medium was added to the top of the chloroplast layer, and the chloroplasts suspension was carefully removed from the bottom layer of sucrose by means of a syringe. Several 
small portions of $W$ medium were carefully added to facilitate chloroplast removal. A repetition of this procedure did not result in any appreciable further purification of plastids since little precipitate formed as a result.

The chloroplast suspension was diluted $I \mathrm{x}$ with cold isolation medium to ensure that the medium was not too dense to prevent the precipitation of the whole plastids. A second $3,000 \times \mathrm{g}$ centrifugation was performed. The sediment consisted chiefly of whole chloroplasts possessing bounding membranes. The supernatant consisted mostly of a small number of broken plastids which were usually discarded. The fraction sedimenting during the second $3,000 \mathrm{X}$ g sedimentation is referred to as the chloroplast fraction. That fraction sedimenting through the $2.5 \mathrm{M}$ sucrose is referred to as the nuclear fraction.

The first 3,000 X g supernatant usually still contained a large amount of membrane-bound chlorophyll. A second. $3,000 \mathrm{Xg}$ or a 10,000 or $20,000 \mathrm{Xg}$ sedimentation falled to removed this pigment and also falled to precipitate the entire amount of chlorophyll from the supernatant. Sedimentation at $30,000 \mathrm{Xg}$, however, removed most of the pigment leaving a greenish or yellowish supernatant which contained mostly alkall labile uv absorbing material. The supernatant was usually discarded. The $30,000 \mathrm{X} \mathrm{g}$ sediment 
which consisted chiefly of broken plastids with some mitochondria and nuclear debris is referred to as the broken plastid or mitochondrial fraction.

\section{Extraction of Nucleic Acids}

Preparation of undenatured nucleic acid from chloroplast and mitochondrial fractions

The fractions were either extracted with detergent and then extracted with phenol or were extracted with phenol alone. The chloroplast and mitochondrial fraction precipitates were suspended in cold $0.01 \mathrm{M}$ Tris, $0.06 \mathrm{M} \mathrm{KCl}, 0.01 \mathrm{M}$ $\mathrm{MgCl}_{2}$. A small aliquot was usually removed at this point for determination of chlorophyll content according to the procedure of Arnon (1949). An equal volume of cold phenol washed with Tris medium was added. The phenolic layer was mixed with the chloroplast suspension by stirring. The phenolic layer was separated from the aqueous layer by centrifugation at $23,000 \mathrm{X}$ f for 10 minutes. The aqueous layer containing the nucleic acids was removed by means of a syringe. One phenol extraction was usually sufficient for complete removal of chlorophyll and the complete denaturation of the proteins. The nucleic acids were precipitated by 2 volumes of ice cold ethanol in which $20 \mathrm{mg}$. sodium acetate per ml of solution had been previously dissolved. The precipitate was suspended in buffer, usually 
$0.15 \mathrm{M} \mathrm{NaCl}$ and $0.015 \mathrm{M}$ sodium citrate (saline-citrate). The solution was dialyzed for 48 hours in the cold against the nucleic acid solvent to remove an optically dense component with an absorption maximum of about $270 \mathrm{mu}$. This component has a similar absorption spectra to phenol. In later experiments it was found that the contaminate could be eluted from a methylated albumin column by low ionic strength buffers such as $0.1 \mathrm{M} \mathrm{NaCl}$ in $0.05 \mathrm{M}$ phosphate buffer $\mathrm{pH} 6.7$. Neither the protein nor any absorbed nucleic acids appeared to be adversely affected by this procedure. All nucleic acid fractions were still elutable from the column when buffers of higher ionic strength were passed through it. The methylated albumin column was prepared according to the procedure of Mandell and Hershey (1960), with all materials doubled.

Extraction of nucleic acids from whole leaves and from bacteria

It was sometimes necessary to extract the nucleic acids from unbroken plant material or from a culture of bacteria. Phenol extraction was the method usually employed. The material to be extracted was placed in an omni-mixer vessel in a medium consisting of Tris medium added in concentration of $1 \mathrm{ml} / \mathrm{g}$ fresh weight of tissue, $1 \mathrm{ml}$ of 40 $\mathrm{mg} / \mathrm{ml}$. bentonite solution for every $10 \mathrm{~g}$ fresh weight of tissue and $1 \mathrm{ml}$ of 2.2 per cent sodium lauryl sulphate per 
$10 \mathrm{~g}$ fresh weight of tissue. An equal volume of Tris washed phenol was added and the material homogenized at full speed for one minute. At that time the omni-mixer was slowed to low speed and the material homogenized at this speed for one minute. A final 1-minute extraction at full speed completed the breakup of the tissues. Less drastic procedures resulted in failure to release all the nucleic acids present. E. coli DNA could be effectively released by grinding the cells in a chilled mortar with alumina followed by phenol extraction of the homogenate. Several extractions with phenol were usually necessary to free the homogenate prepared from whole cells of protein.

Purification of the extracted nucleic acids

Separation of the DNA from the RNA: Since RNA has a similar absorption spectra to DNA, it was necessary to remove it if any estimation of the amount of DNA present was to be made by optical means. RNA was partially degraded by digestion with Bovine pancreatic RNAase (Sigma Ribonuclease fraction XIIA). An equal volume of the enzyme solution was added to the sample. The concentration of enzyme was 0.1 $\mathrm{mg} / \mathrm{ml}$ in acetate buffer $\mathrm{pH}$ 6.0. The digestion was allowed to proceed for one hour at room temperature. The enzyme was removed by adding $1 \mathrm{ml}$ of bentonite suspension ( $40 \mathrm{mg} / \mathrm{ml}$ ) and centrifuging down the bentonite. The degraded RNA was separated from the DNA by absorbing it onto a methylated 
albumin column and eluting the degraded RNA with $0.35 \mathrm{M}$ $\mathrm{NaCl}$. In $0.5 \mathrm{M}$ phosphate buffer $\mathrm{pH} 6.7$. The DNA not hydrolyzed by the enzymatic digestion remained on the column. It was eluted from the column by using buffered $1.0 \mathrm{M} \mathrm{NaCl}$. Separation of contaminating nuclear DNA from chloroplastic DNA

Detergent extraction of chloroplasts: Brawerman and Eisenstadt (1964) found that it was possible to separate chloroplast DNA from nuclear DNA by extraction of the plast1d suspension with a detergent, 5 per cent sodium deoxycholate. Chloroplasts were suspended in $100 \mathrm{ml} 0.01 \mathrm{M}$ Tr1s buffer $\mathrm{pH}$ 6.7 containing $0.01 \mathrm{M} \mathrm{MgCl}_{2}$. Five $\mathrm{ml}$ of $5 \%$ sodium deoxycholate were added to the chloroplast suspension and the suspension was carefully mixed. Chloroplast fragments were precipitated by a 30 - minute $30,000 \times \mathrm{g}$ centrifugation. If sucrose was present in the medium to any degree, the plastid fragments tended to remain in suspension even after centrifugation at $30,000 \mathrm{Xg}$. Sucrose was often carrled over from earlier parts of the experiment. A preliminary washing with Tris was often necessary to remove this material. 
Characterization of the DNA fractions isolated

Cesium chloride gradient centrifugation: Chloroplast DNA may be separated from other kinds of DNA by cesium chloride gradient centrifugation. Optical grade $\mathrm{CsCl}$ obtained from Alfa Inorganics, Beverly, Massachusetts, was made up in 0.02M Tris buffer $\mathrm{pH}$ 8.5. This stock solution of saturated CsCl which had a mass density of about 1.9239 $\mathrm{g} / \mathrm{cm}^{3}$ was diluted to the required density with a solution of DNA in Tris buffer. The density of the CsCl solutions was determined by measuring the index of refraction of the solutions by means of a refractometer. A formula given by Vinograd and Hearst (1962) relating index of refraction to buoyant density was used to calculate these values.

At first, rotor 39.1 of the Spinco Model I preparative ultracentrifuge was used. The DNA containing CsCl solutions were adjusted to a density of 1.700. E. coli DNA was used as a marker and the solutions were centrifuged at $120,000 \mathrm{Xg}$ for three days at $18-19^{\circ} \mathrm{C}$. Later an attempt was made to form a gradient by mixing solutions of $\mathrm{CsCl}$ of known densities. The gradient employed called for a $6 \mathrm{ml}$ preformed gradient using $3 \mathrm{ml}$ of a $\mathrm{CsCl}$ solution of density 1.800 and $3 \mathrm{ml}$ of one of density 1.600. The low density solution was placed in the mixing chamber of a plexiglass gradient maker, the higher density one was placed in the other chamber. All connecting spaces were filled with liquid to prevent the formation of 
alr bubbles. A slight alr pressure was applied to each chamber. The connecting valves were opened slightly to the same degree and the two liquids allowed to $\mathrm{mix}$ together with the magnetic stirrer operating at full speed. The hypodermic needle attached to the effluent opening was placed as near to the bottom of the centrifuge tube as possible without preventing the flow of the solution. Every precaution was taken to prevent the mixing of the preformed gradient during manipulations before centrifugation. Samples were placed In $\mathrm{CsCl}$ solution of density 1.600 and added to top of gradient. According to Fisher, Cline and Anderson (1964) a fixedangle rotor will also permit the establishment of a linear gradient within it which remains undisturbed by the reorientation of the tube contents when the sample is removed from the rotor. Since rotor 39.1 of Beckman Model L ultracentrifuge was not always avallable, rotor 50, a f1xed-angle rotor, was used in 1ts place.

The hemispherical portion of the centrifuge tube was filled with a dense liquid, usually a CsCl solution of density the same or greater than the most dense portion of the gradient. The portion of the tube unoccupied by liquid or cap was filled with mineral o11. The preformed gradient was centrifuged at $120,000 \mathrm{X} g$ for $12-24$ hours. The temperature of the internal chamber of the centrifuge was maintained close to $25^{\circ} \mathrm{C}$.

After centrifugation the tubes were removed from the rotor and the caps were taken off. A hole was punched in 
each tube using a tube punching apparatus adapted from a design by Salo (1965). A piece of rubber tubing exactly fitting the outside of the centrifuge tube, but permitting the tube to slip inside, was selected. A rubber stopper was fitted into one end of the tubing. A hypodermic needle was punched through the cork and the cork was held strongly by means of a clamp. A number 20 needle was used for this purpose. The sharp end of the needle was set in the correct place to collect the gradient without collecting the solution occupying the hemispherical portion of the tube. A soft rubber septum from a syringe bottle was used to seal the place where the needle penetrated the stopper to prevent the leakage of gradient material at these points. A hole had been pierced in the cork at a spot not touched by the bottom of the centrifuge tube to prevent mixing of the gradient.

Five drops were collected from the end of the needle in each collecting tube. The uv absorbance in each tube was determined on a Beckman DB spectrophotometer using a deionized water blank. The samples were read in a microcuvette having a critical volume of $0.3 \mathrm{ml}$ and a light path of $0.1 \mathrm{~cm}$. 


\section{Analytical Procedures}

DNAase treatment: Sigma Bovine Pancreatic DNAase Fraction XII was made up in $0.001 \mathrm{MgCl}_{2}$ and $0.01 \mathrm{M}$ phosphate buffer pH 7.0 to a final concentration of $1 \mathrm{mg} / \mathrm{ml}$. The volume of DNAase added to the sample was one-tenth of the sample volume. The solution was allowed to stand at room temperature for an hour and the enzyme was removed by precipitation with bentonite. This treatment provided sufficient depolymerization so that the DNA was eluted from a methylated albumin column with $0.35 \mathrm{M} \mathrm{NaCl}$ instead of $1.0 \mathrm{M}$ $\mathrm{NaCl}$.

Acid extraction and colorimetric determinations: In some cases it was not necessary to have undegraded DNA. Acid extraction procedures were used in those cases. The sample was treated with an equal volume of cold $1.0 \mathrm{M} \mathrm{HClO}_{4}$. With large volumes a small volume of cold concentrated perchloric acid was used to bring the concentration of the acid in the sample to $0.5 \mathrm{M}$. After centrifugation, the acid soluble portions were discarded and the precipitate was first washed with ethanol; then with a mixture of ether, chloroform, and ethanol (2:1:2) by volume to remove chlorophyll and lipids. RNA and DNA were solublized by hot acid extraction at $70-90^{\circ} \mathrm{C}$ for 15 minutes. RNA was sometimes removed before the hot acid hydrolysis by alkaline hydrolysis using an equal volume of $0.6 \mathrm{~N} \mathrm{KOH}$ for 18 hours at room temperature. Colori- 
metric tests were made on the acid hydrolysate. The diphenylamine procedure of Burton (1956) was commonly used. Hydrolysis of DNA: DNA was hydrolyzed by an enzymatic procedure in which the molecule was first attacked by pancreatic DNAase and then by phosphodiesterase Sigma type II isolated from snake venom. The enzyme was removed by treating the solution with $0.5 \mathrm{M} \mathrm{HClO}_{4}$ and filtering the material through a millipore filter paper. The solution was neutralized and its volume reduced in a boiling water bath. Nucleotides released were separated by thin layer chromatography, and the nucleotides eluted from the cellulose and estimated by uv absorption. These experiments were not completed. Acid hydrolysis of DNA was also tried; $0.5 \mathrm{M}$ acid was used to release the purines. Thin layer chromatography

DEAE cellulose powder ( $M N$ cellulose powder 300 DEAE) was obtained from Brinkman Instruments, Great Neck, New York. The powder was washed with $500 \mathrm{ml}$ of a mixture of $0.1 \mathrm{M}$ formic acid and $0.1 \mathrm{M}$ sodium formate. This washing was necessary to remove iron compounds which were heavy contaminants of the powders imparting to them a yellow color. The cellulose was spread on glass plates and dried. Nucleotide separation was best obtained with a solvent made up of saturated ammonium sulfate, 2.0M sodium acetate, and isopropanol (88:18:2). 


\section{$\underline{\mathrm{p}^{32} \text { labelling experiments }}$}

The tops of pea plants were cut off with a razor blade at the lowest node and the cut end placed into deionized water containing the $\mathrm{P}^{32}$. Most often the amount of $\mathrm{P}^{32}$ in the solution was $50 \mathrm{uc}$ in $25 \mathrm{ml}$ of deionized water. The chloroplasts were prepared and extracted as described previously. Counting was done on a Nuclear Chicago gas flow counter in stainless steel planchets.

DNA melting point determinations

Isolated DNA was suspended in saline-citrate. The sample was heated in a cuvette within the chamber of a Beckman DU spectrophotometer fitted with thermospacers and insulators. The thermospacers contained tubes permitting the circulation of water from a Precision Scientific Circulating water bath controlled by a mercury thermoregulator. The phototube and the optical portions of the DU were protected from overheating by another set of thermospacers in which water at room temperature was circulated. A single cuvette next to the sample we was fited with a thermocouple wire attached to a potentiometer calibrated in even numbered degrees Fahrenheit. Thus it was possible to read to the nearest whole degree Fahrenheit. It was possible to follow the increase in optical density of the DNA solution as the temperature was slowly increased. The procedure followed and the calculations used in determining the base composition of the sample were those of Marmur and Dotty (1962). 
RESULTS

The use of methylated albumin columns in the fractionation of nucleic acid extracts

In this work, methylated albumin columns were used extensively in the final stages of preparation of nucleic acids. The methylated albumin combines with nucleic acids. Increasing, the ionic strength of the medium causes the release of the nucleic acid from the protein in a characteristic manner. Two methods were used to elute the nucleic acid from the protein. In the first method, a linear gradient elution with sodium chloride was used. Nucleic acids appear in a characteristic sequence from the column. In the second method, known volumes of specific concentrations of sodium chloride were added to the column. The different species of nucleic acids were eluted at different concentrations.

Figure 1 shows two uv absorption tracings of an eluate from the column passing through a cuvette and intercepting a uv light beam. The size and height of the peak arising from this procedure depends on a number of factors, such as flow rate of sample through cuvette, other than the amount of nucleic acid species present. This makes it unlikely that these will provide direct information about the 


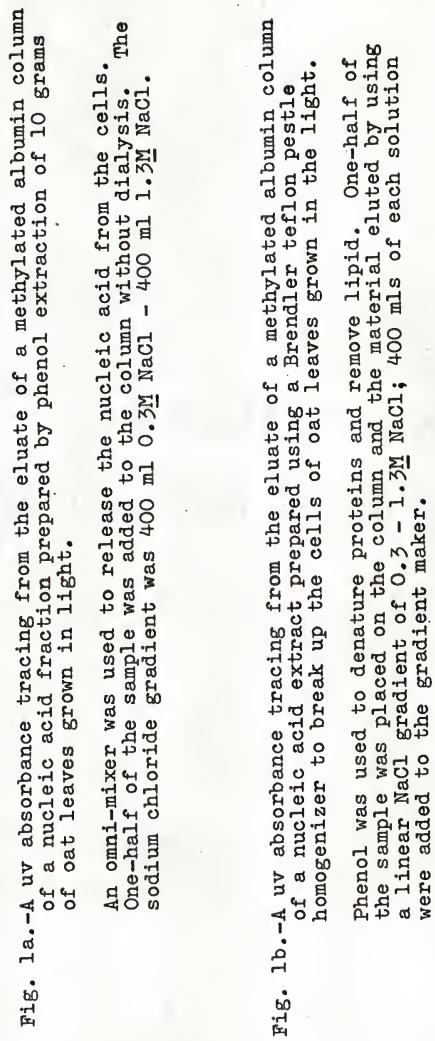



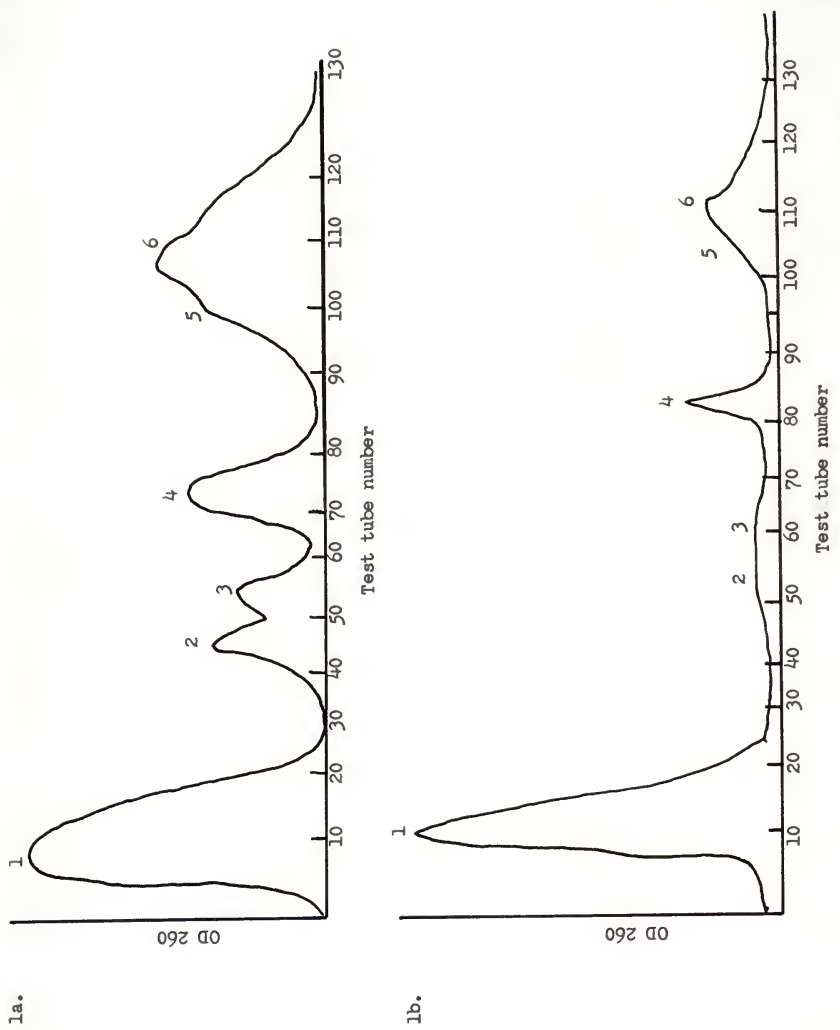
amounts of nucleic acid in each fraction. Rather, it was necessary to read the amount of absorbancy at $260 \mathrm{mu}$ of each fraction on a Beckman DB spectrophotometer to be certain of this. In most experiments this was not done.

The sequence in which the nucleic acids species are eluted from the column was usually the best diagnostic test for their identity. Figure la shows a tracing of an eluate from a methylated albumin column eluted by a linear salt gradient. The column was loaded with half of a sample of nucleic acids prepared from 10 grams of oat leaves. Six peaks are evident. The first peak is phenol. Its absorption maximum is at $270 \mathrm{mu}$. All other peaks showed absorption maxima at $260 \mathrm{mu}$ or slightly below. These peaks were sensitive to RNAase. Either the peak completely disappeared or lost a considerable amount of uv absorbing material when sample was treated with the enzyme. The uv absorbing material usually appeared in the first soluble RNA peak. (See Figure 5). Peak 4 was always partially resistant to RNAase treatment. DNAase treatment, however, caused the peak to completely disappear. The uv absorbing material from this peak eluted within the first twenty fractions collected. This is true for all peaks whose material was sensitive to the enzyme. No other peaks were sensitive to DNAase. Thus, peak 4 was belleved to be made up of a DNA/RNA complex of non-specific nature. All other peaks are entirely due to different RNA species. 
Peaks 2 and 3 usually occur in such small amounts that it is difficult to tell if they are present or not. The large amount of nucleic acid that is present in this sample was the reason that so much uv absorbance appeared in these fractions. These two peaks are probably due to soluble RNAs of the transfer variety. The last two peaks, 5 and 6 , are due to ribosomal RNA usually present in the highest concentration of all nucleic acids in the samples. The base composition of the RNA in these peaks resembles that reported for ribosomal RNA in the literature. These two peaks usually overlap although the boundary between them is somewhat hard to ascertain in many tracings.

This sequence of nucleic acid elution is not changed by many factors which change the shape and size of the peak. Factors such as flow rate and steepness of the salt gradient used as eluting agent, can change the size and shape of the peak as well as the fraction into which the peack is eluted, but do not change the sequence which nucleic acid species are eluted. This is indicated by comparing Figure $1 \mathrm{~b}$ and Figure la. The same sequence of elution is shown by samples prepared by two different procedures. The sample shown in Figure lb was prepared by using a Brendler cell homogenizer. This treatment does not release as many of the cellular nucleic acids as the omni-mixer used to prepare sample in Figure la. Yet, the two-humped ribosomal RNA peaks appear near the end of 
the gradient. Peak 4, the DNA/RNA peak was eluted within ten tubes of the oibosomal RNAs. The soluble RNA peaks are so small that they are difficult to see on the tracing from the column.

Fractionation of nucleic acids isolated from the chloroplast fraction

When nucleic acids extracts from chloroplast samples were placed on a methylated albumin column the results were equivocal. Figure 2 shows a tracing from a chloroplast fraction isolated from oat leaves. One peak of uv absorbance is present. This peak has an absorption maximum at $260 \mathrm{mu}$. Color tests were not performed because the material was used up in running $\mathrm{CsCl}$ gradients. The absence of other peaks in the eluate made identification of the peak difficult. This was the first good evidence for the presence of nucleic acid in the chloroplast fraction found in this project.

The tracing obtained from phenol extracted chloroplasts from dark grown oat leaves exposed briefly to light gave more definitive results. These are shown in Figure 3. Since optical density readings of the contents of most of the test tubes were taken, more meaningful information is conveyed by this figure than was possible with the others. Three peaks appeared. The third peak was probably due to ribosomal RNA. These ribosomes came from the chloroplasts since a peak at this position was never found in tracings of 


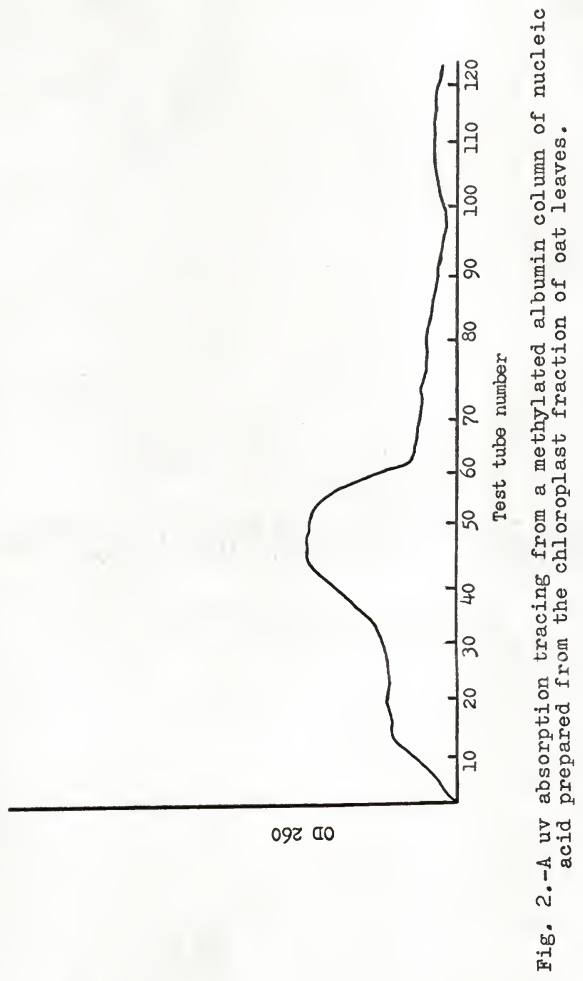




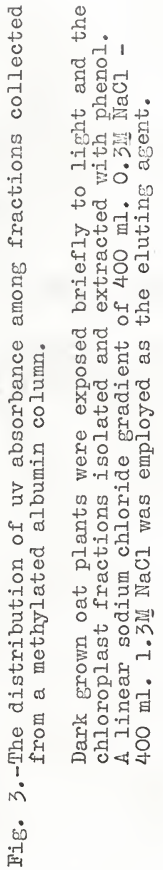




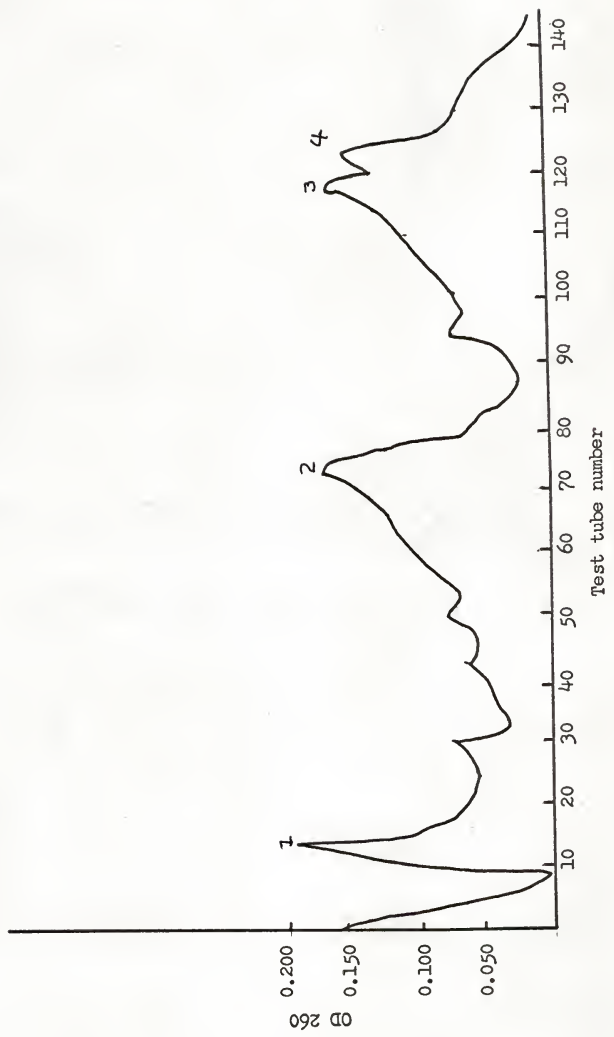


extracts made from chloroplasts of light grown leaves as would be expected if microsomal ribosomes were contributing to this peak. (Figures 2 and 4 ). A high RNA content was also indicated by results found with acid fractionation of chloroplast fractions using the procedure of Ogur and Rosen (1950). Cold extraction of acid insoluble material for 18 hours with $1 M$ perchloric acid supposedly results in the solution of RNA, leaving any DNA present in the residue. The cold acid extract of a chloroplast fraction from dark grown plants exhibits greater uv absorbance than that of light grown plants (see Table 1). Smlllie, Evans, and Lyman (1963) found that dark grown Euglena chloroplasts had higher RNA content than those exposed to light for periods greater than 12 hours. After this time the RNA content fell to a level markedly below the 12 hour level. Peak 2 is probably a DNA peak but corroborative evidence is lacking.

Figure 4 shows a tracing obtained from the chloroplasts of light grown mustard green leaves. The second uv peak is in the approximate position of the second peak of Figure 3. No other tests were run on this sample. The distribution of nucleic acids among fractions prepared during the isolation of chloroplasts

The distribution of DNA in the different fractions prepared during the isolation of chloroplasts from pea leaves was studied by means of their uv absorbance spectra 


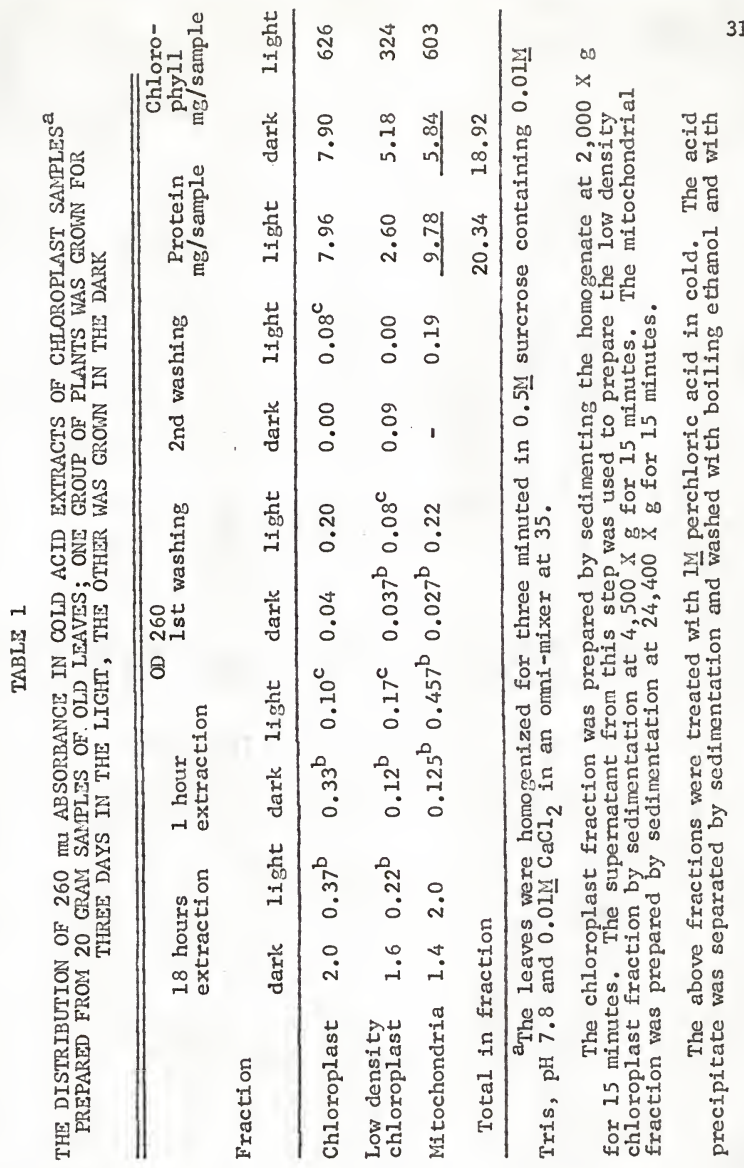




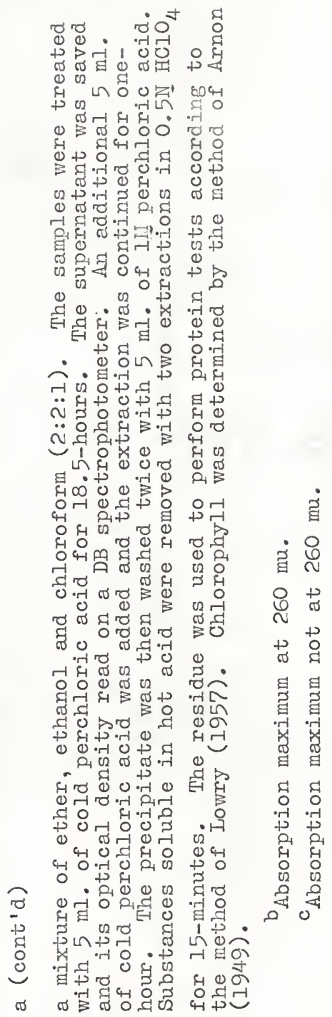




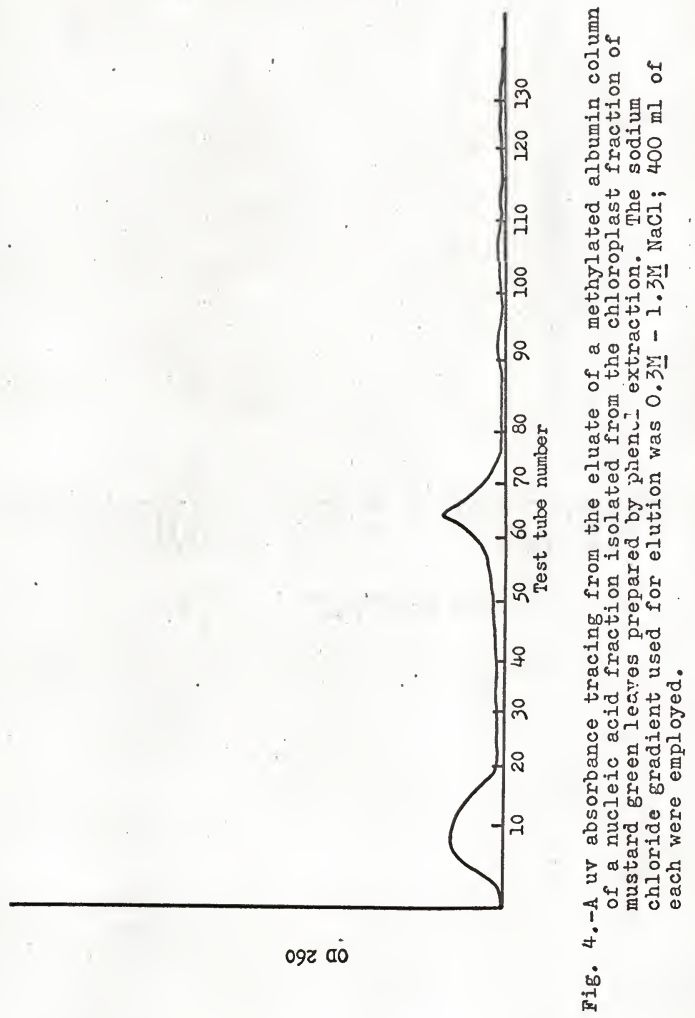


and the spectra of the blue colored substance formed by the reaction of diphenylamine with deoxyribose. Tables 2 and 3. The results obtained were not consistant because of the low sensitivity of the diphenylamine (DPA) reagent to low concentrations of DNA. Larger amounts of material or more sensitive methods such as those in the next section were needed.

Detergent extraction of chloroplasts

Chloroplasts contain two types of membrane systems: an internal one and an external one. Evidence summarized in the discussion section suggested that the chloroplast DNA is bound in some manner to the internal membranes which are not destroyed by detergent treatment. The external membranes are ruptured by the treatment. Nuclear membranes are known to be more fragile than chloroplast internal membranes. It is extremely difficult to prepare whole nuclei from plant cells using the techniques employed to isolate chloroplasts. No free nuclei were ever demonstrated in these experiments in preparations stained by the acetocarmine, acetoorcein or Fuelgen procedures. Detergent treatment should provide a means of solubilizing the nuclear fragments associated with the chloroplast fraction while retaining the chloroplast DNA inside the lamelia system which sediments at $30,000 \mathrm{X} \mathrm{g}$. Table 4 showed evidence that a uv absorbing material was released from the plastids by detergent treatment. DPA tests were negative. The sample may have been too small 


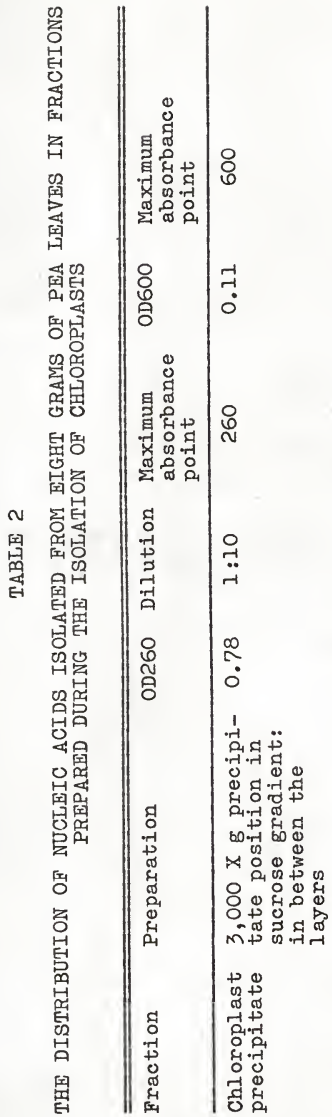

ㅇำ

$\begin{array}{lll}\text { กิ } & \text { กิ } & \text { กิ } \\ 0 & 0 & 0 \\ 0 & 0 & 0\end{array}$

กี

$\begin{array}{lll}0 & 0 & 0 \\ \ddot{H} & \ddot{H} & \ddot{H}\end{array}$

寺 $\begin{array}{ll}\text { मे } \\ 0\end{array}$

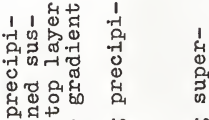

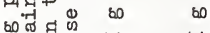

$\triangle$ घंत्र $x$

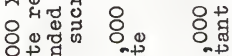

娄

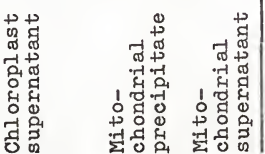




\section{TABLE 3}

THE DISTRIBUTION OF NUCLEIC ACIDS AMONG FRACTIONS* PREPARED DURING CHLOROPLAST ISOLATION FROM TEN GRAMS OF PEA LEAVES

\begin{tabular}{ccccc}
\hline Fraction & OD260 & Dilution & $\begin{array}{l}\text { Maximum ab- } \\
\text { sorption } \\
\text { point }\end{array}$ & OD600 \\
\hline 1 & 1.2 & $1: 1$ & 260 & 0.00 \\
2 & 0.79 & $1: 1$ & $260-270$ & 0.00 \\
3 & 1.60 & $1: 1$ & 260 & 0.00 \\
$\begin{array}{c}\text { Chloroplast } \\
\text { precipitate }\end{array}$ & 0.791 & 0 & 270 & 0.00
\end{tabular}

$270 \mathrm{mu}$ maximum probably phenol

*The leaves were ground in $W$ medium in a mortar. Chloroplasts in the homogenate were recovered by placing the extract over $10 \mathrm{ml}$ of $1.5 \mathrm{M}$ sucrose and centrifuging at $32,449 \mathrm{X} g$ for 15 minutes. Fraction 1 was the material remaining in the $\mathrm{W}$ medium, the first layer of the discontinuous sucrose gradient. The chloroplasts were resuspended in $W$ medium after removal from discontinuous gradient by means of a syringe. The chloroplasts formed a layer between the two layers of sucrose solutions. The resuspended chloroplasts were re-precipitated by centrifugation at $30,000 \mathrm{X} \mathrm{g}$. The supernatant was used to prepare fraction 2. Fraction 3 was prepared from the $1.5 \mathrm{M}$ sucrose layer. The chloroplast fraction was extracted with phenol and a part of it used in the color test. Each fraction was extracted with alcohol and acid and nucleic acids were solubilized by hot acid treatment. 
or the DNA degraded to such an extent that little was left. Tables 5 and 6 show that DNA is present in the detergent supernatant fraction. Brawerman and Eisenstadt (1964) reported that a DNA present in the detergent supernatant fraction was recoverable by centrifugation at $100,00 \mathrm{x} \mathrm{g}$ for two hours. This procedure was repeated using the pea material. No DNA was detected by DPA activity, uv absorbtion or methylated albumin chromatography using a buffer system which had been successful in separating the different nucleic acid fractions from com and pea samples.

The presence of nucleic acids in the detergent precipitates was much more difficult to show. The samples recorded in Tables 5 and 6 gave inconclusive DPA tests. A larger sample was needed. The results of using a larger sample are recorded in Table 7. Clearly both the detergent precipitate and supernatant fractions contain DNA.

The above tests are somewhat equivocal. The method used is somewhat insensitive and it is difficult to demonstrate the presence of DNA in every sample run. For this reason the more sensitive methods reported in the next section were developed.

The demonstration of the presence of DNA in extracts of chloroplast-containing fractions by means of nuclease treatments and methylated albumin column chromatography

Unequivocal demonstrations of the presence of DNA in fractions of isolated chloroplasts were very difficult. The DNA of the chloroplast was in such small amounts that it was measured by ordinary colorimetric determinations with difficulty. 


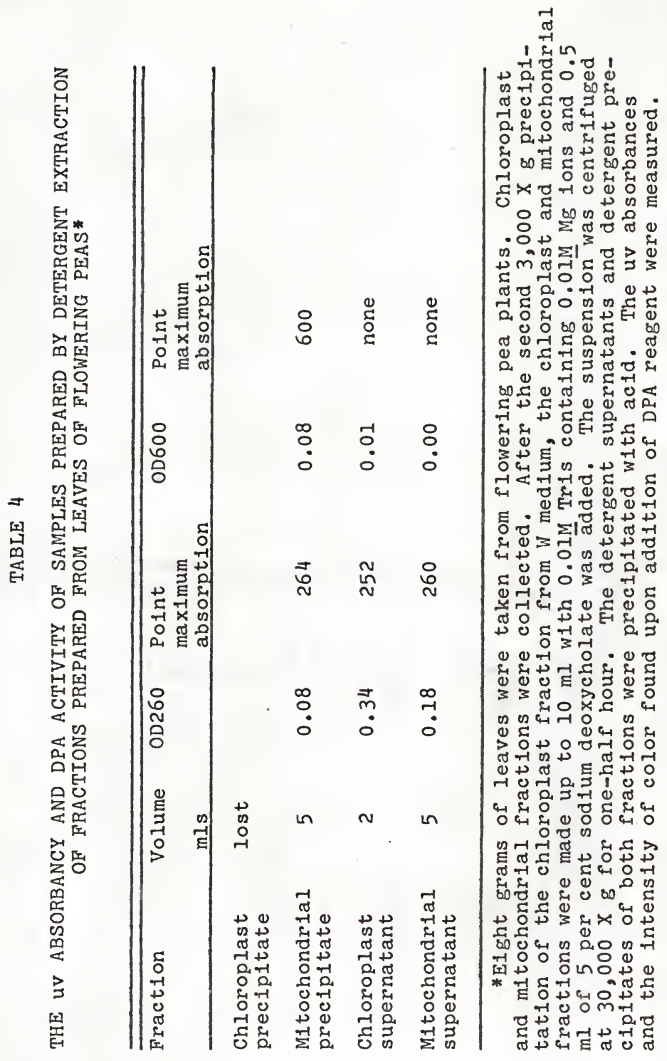




\section{TABLE 5}

THE UV ABSORBANCE AND DPA ACTIVITY OF DETERGENT SUPERNATANTS PREPARED FROM TURNIP GREUNS IEAVES*

\begin{tabular}{llllc}
\hline \hline Fraction & OD260 & $\begin{array}{l}\text { Point of } \\
\text { maximum } \\
\text { absorbance }\end{array}$ & OD600 & Dilution \\
\hline Nucleus & 0.78 & $260-264$ & 0.115 & $1: 4$ \\
Chloroplast & 0.76 & $264-266$ & 0.105 & 0 \\
\hline
\end{tabular}

*Chloroplasts were prepared from the meristematic region and the youngest leaves of field grown turnip greens. A large amount of material was collected and immediately frozen in acetone/dry 1ce. The detergent precipltates of two runs were combined and saved for further study. The chloroplast fraction contained not only the material between the two layers but also that suspended in the upper layer. The plastids were suspended in $160 \mathrm{ml}$ of $0.01 \mathrm{M}$ Tris $\mathrm{pH} 7.7$ and $0.01 \mathrm{M} \mathrm{Mg}$ ions. Seventeen $\mathrm{ml}$ of sodium deoxycholate were used. The detergent supernatant was adjusted to $0.5 \mathrm{~N} \mathrm{HClO}_{4}$. The acid precipitates were washed with alcohol and solubilized by heating at $70^{\circ} \mathrm{C}$ for 15 minutes. The detergent precipitates were extracted with phenol and saved for further work. 


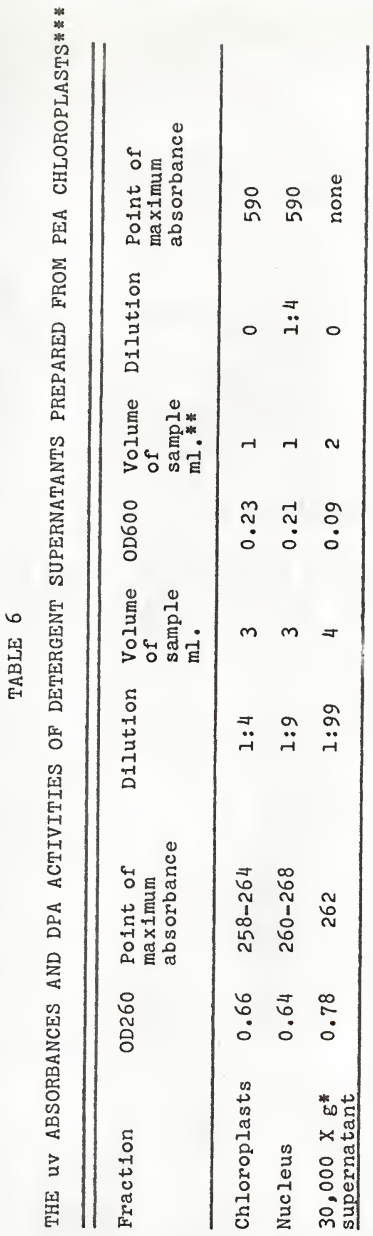

대욤

द्व 1020

सो $\Omega_{1}$ \& 30

02 नो

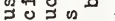

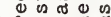

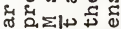

+ เ⿵人

है

๙ 0 ช ชู

๙ 0 थ

टी व 0 के

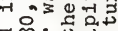

을 क्ष

ङ

है स्त्र 0 कू

$\infty$ 요욤

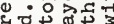

4 वृम क्षे

3

幽

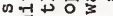

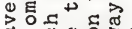

ชึ

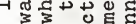

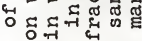

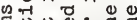

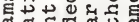

๘

का כण्त

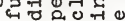

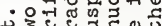

ए

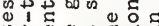

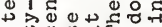

फ 0 व $\mathrm{E}$

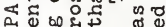

A 10 है

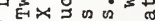

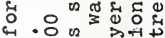

¿ ध

c

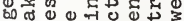
60 (1) है E्व है 30 क फ 0 व 0 फा

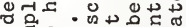

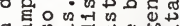
द ते थन च व 0 b०

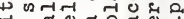

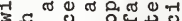

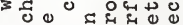
ช ช \& (1) 30 ठ

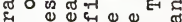
स $\rightarrow$ \& त्र

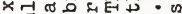

$\omega$ ह 90 ग

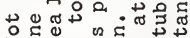

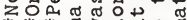
* * $* 3$ ¿ 30 व ** न * 들 Ð न ब 


\section{TABLE 7}

THE $600 \mathrm{mU}$ ABSORBANCE OF DPA TREATED PHENOL EXTRACT OF DETERGENT PRECIPITATED CHLOROPLASTS ISOLATED FROM 21 GRAMS OF PEA LEAVES*

\begin{tabular}{lcc}
\hline Fraction & OD 600 & $\begin{array}{c}\text { Maximum Absorption } \\
\text { Point }\end{array}$ \\
\hline $\begin{array}{l}\text { Detergent } \\
\text { precipitate }\end{array}$ & 0.18 & $590-600$ \\
$\begin{array}{l}\text { Detergent } \\
\text { supernatant }\end{array}$ & 0.15 & $\begin{array}{c}\text { Approximately } \\
590\end{array}$ \\
\hline
\end{tabular}

*Twenty-one grams of pea leaves were pulverized in a mortar. A small amount of alumina was added and 16.9 grams of solid sucrose was added to the $W$ medium. The homogenate was centrifuged at $30,000 \mathrm{X}$ g. The precipitate was suspended above $2.5 \mathrm{M}$ sucrose and centrifuged 15 minutes in rotor 25.1 at $32,449^{-} \mathrm{X} g$ in a model I preparative ultracentrifuge. The chloroplasts were removed from the interface between the solutions and re-precipitated by centrifuging at $30,000 \mathrm{x} g$ for 15 minutes. Detergent treatment as described previousiy was carried out. An equal volume of chloroform, isoamyl alcohol $(24: 1)$ by volume was added to the detergent supernatant and the supernatant was stirred vigorously with a magnetic stirrer for one-half hour at room temperature. This procedure was adapted from a method of Marmur (1961), and was more convenient for large volumes of liquid, since the chloraform does not absorb at $260 \mathrm{mu}$. The two liquids are separated easily in a separatory funnel.

The detergent precipitate was extracted with phenol. Protein was removed from the aqueous phase to prevent its reaction with the DPA reagent interfering with the determinations. Each sample was treated with acid and the acid preclpitate defatted with absolute ethanol. The precipitate was treated with $1 \mathrm{ml}$ portions of $0.5 \mathrm{~N} \mathrm{HClO}_{4}$ at $70^{\circ}-85^{\circ} \mathrm{C}$. The acid extract was filtered through ${ }^{-}$a No. I filter paper and treated with diphenylamine reagent for 18 hours at room temperature. The samples were read in a Beckman DB spectrophotometer where the DPA blank in the sample position was set to zero against a de-ionized water blank. 
The $\mathrm{p}^{32}$ labeling coupled with use of a purified DNA as a marker and the selective washing of methylated albumin columns overcame many of these difficulties.

In the first experiment of this series, nucleic acids were prepared by phenol extraction from the chloroplast and mitochondrial fractions of rooted peanut cuttings. The extract was treated with RNAase and the degraded RNA removed from the DNA by methylated albumin chromatography using a linear sodium chloride gradient. Phenol and other impurities were washed off the column using a low lonic strength buffer before the gradient was turned on.

The place where the DNA was eluted was located by using a sample of phenol extracted corn nucleic acids freed from the RNA components by the above procedure. Figure 5 shows an uv absorbance tracing of the marker corn sample before and after RNAase treatment. Test tubes 60 - 80 of the later sample were used as the marker.

The test tubes in the vicinity of the DNA marker eluted from the methylated albumin column along with the peanut sample were chosen for counting. Uv absorbance was read on a Beckman DB spectrophotometer. Acld precipitable material was collected on a Millipore filter paper and counted on a Muclear-Chicago gas flow counter. 


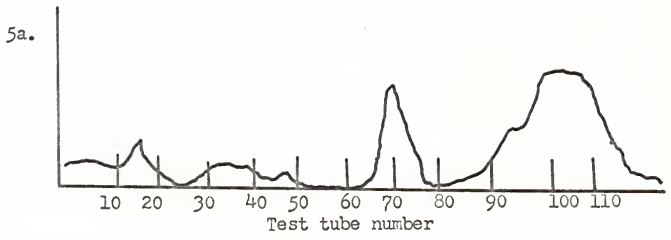

Fig. 5a.-A uv absorbance tracing of an eluate from a methylated albumin column. The sample was phenol extracted corn stem tips. The sample was untreated with RNAase. The DNA peak was used as a marker in experiments utilizing the chloroplast fraction from pea leaves.

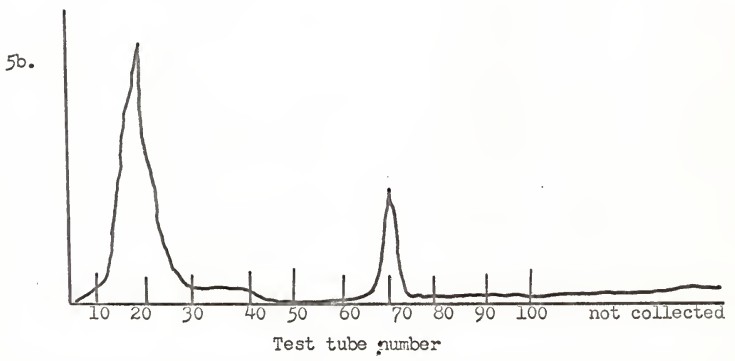

Fig. 5b.-A uv absorbance tracing of the other half of the corn sample shown in 5a. The sample was extracted with RNAase for one hour at room temperature. 
The results of this experiment, shown in Figure 6, indicated that $\mathrm{P}^{32}$ was incorporated into the DNAs of the peanut chloroplast fraction. The amount of incorporation is very slight, however. Using the gradient it was found that the $\mathrm{P}^{32}$ peaks and the uv absorbance due to corn DNA overlap. It is not known whether the peaks would correspond better if pea nucleic acid were used instead.

This experiment was repeated using pea plants as the nucleic acid source. The nucleic acids were prepared, purified and counted using the same procedure as in the previous experiment except that fifty $\mathrm{ml}$. allquots of known concentrations of salt were used to elute the sample from the methylated albumin column. Degraded RNAs were first removed by washing the methylated albumin column with $0.35 \mathrm{M}$ NaCl. DNA was eluted by the second $50 \mathrm{ml}$ aliquot of $1.0 \mathrm{M} \mathrm{NaCl}$. $0.35 \mathrm{M}$ salt did not elute it. Lower concentrations of salt did not elute the DNA. Results of this experiment are shown in Figure 7. The peak in radioactivity did not correspond to the peak in uv absorbance due to the com DNA marker. However, the radioactive peak was eluted in the same position as the absorbance peak in most of the experiments. The pattern of uv absorbance elution found in this experiment is greatly different from that found in all other experiments. Most often an exact correspondence between $\mathrm{P}^{32}$ counts and uv absorbance was found. 
OD 260

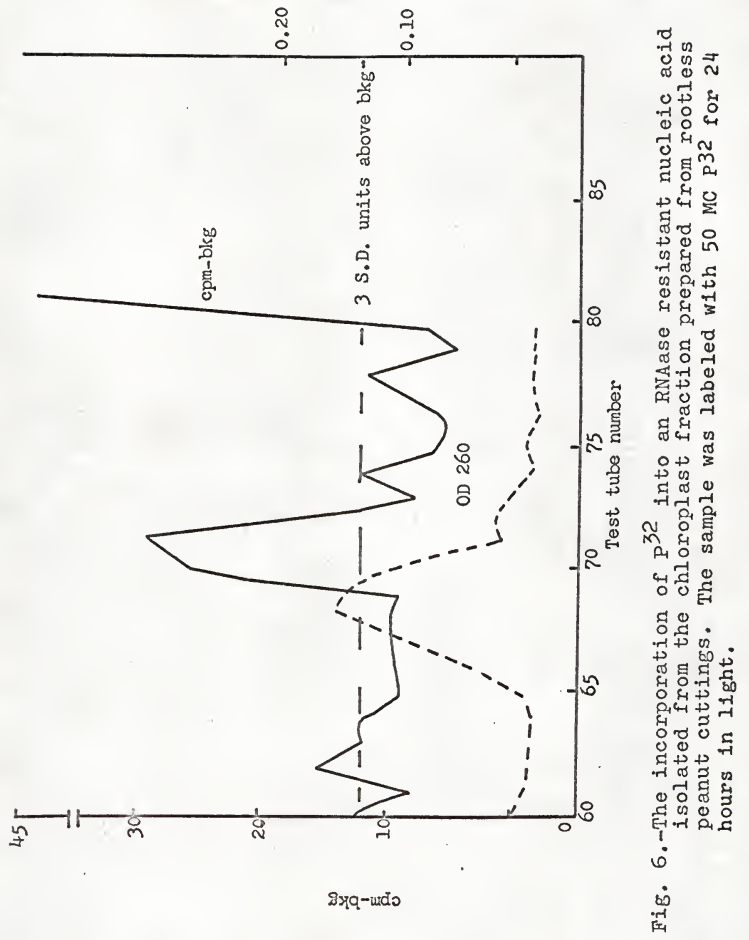




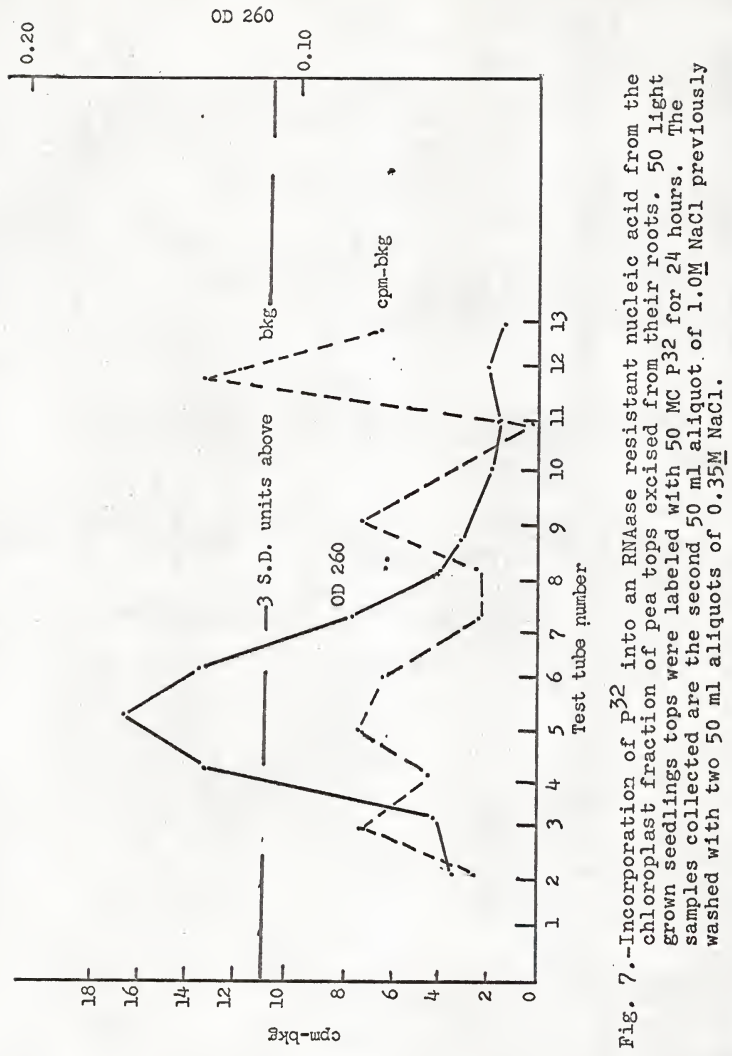


A third experiment was performed to see if excision of pea roots affected the results. Two batches of lightgrown seedlings were selected. One batch had its roots excised, the other was left intact. Both were labeled with 50 uc P32 for 24 hours. Nucleic ac1ds were prepared, pur1fied and counted as before. 1.2M NaCl was used to elute the DNA in this case only. The results of these experiments are recorded in Figures 8, 9, and 10. The DNA uv absorbance is again due to corn DNA. The absorbance and the count peaks coincide. The excised material apparently accumulated more counts in the chloroplast fraction's nucleic acids than the rooted plants did. This result is based on one experiment. It was decided to remove the roots in all the following experiments because no definite harm seemed to have occurred to the plants by such excisions.

Another group of experiments was undertaken in which the chloroplast and mitochondrial fractions were extracted with 5 per cent deoxycholate. As shown in Figure 11 the detergent precipitate shows a $\mathrm{P}^{32}$ count distribution similar to that found in previous work. The uv absorbance peak corresponds with the $\mathrm{P} 32$ count peak. Figure 12 reveals the fact that the $100,000 \mathrm{Xg}$ precipitate from the detergent supernatant fraction shows only doubtful incorporation of $\mathrm{P}^{32}$. 
cpm-bkg

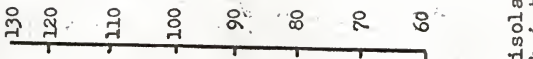

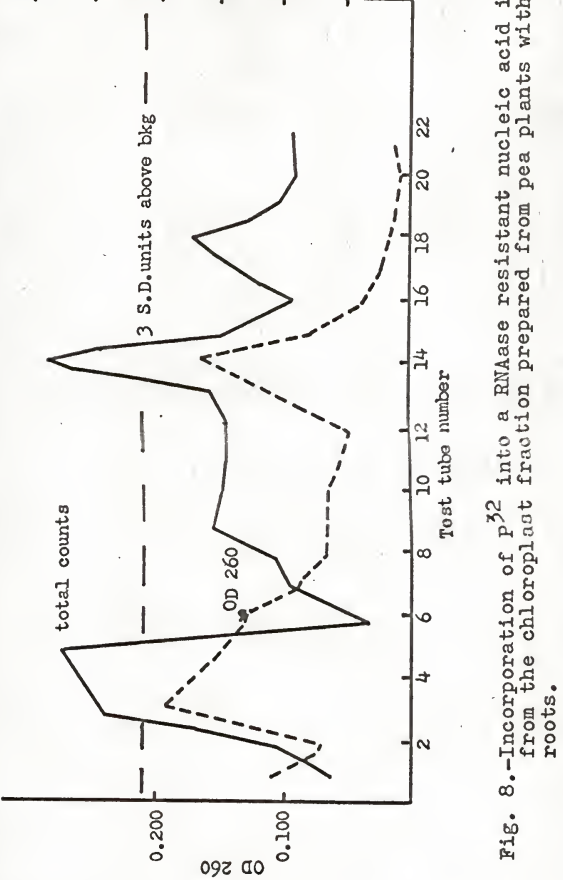


Counts per 5 minutes

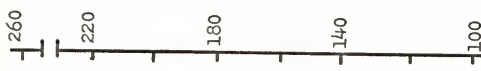

궁

(1)

गु

द्व

,

\&

कै

of $\mathrm{A}_{1}$

요

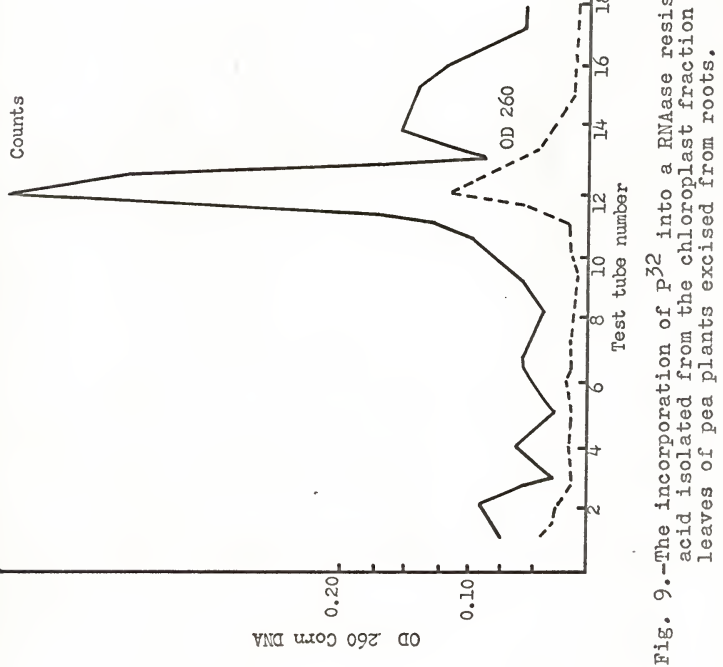




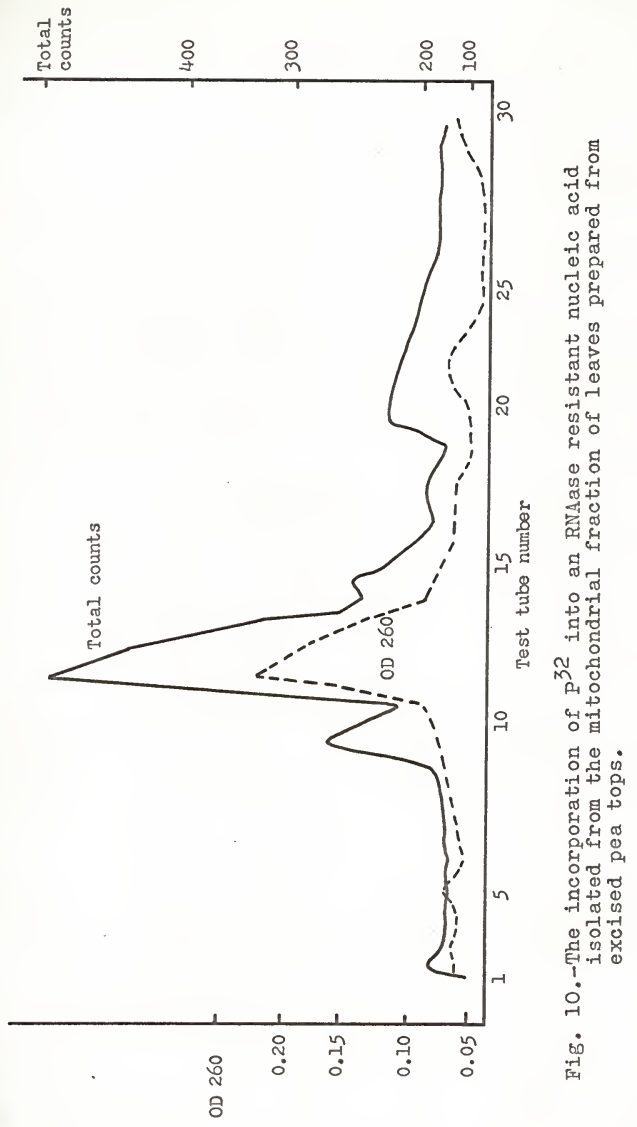




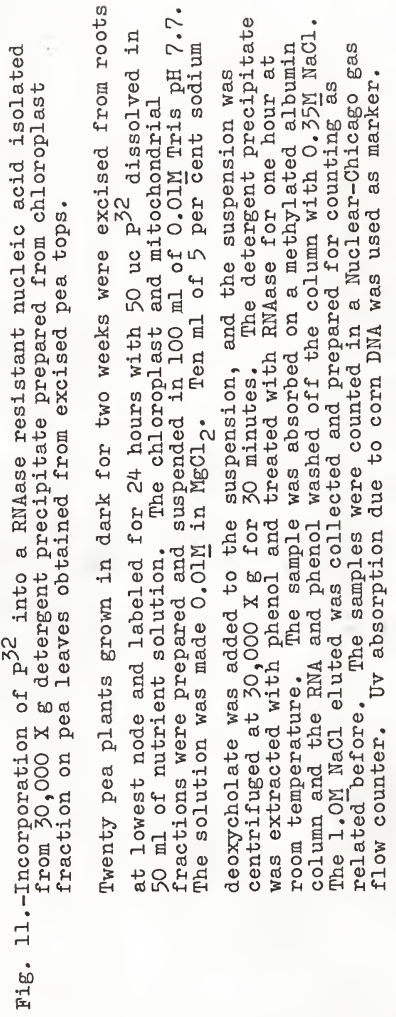




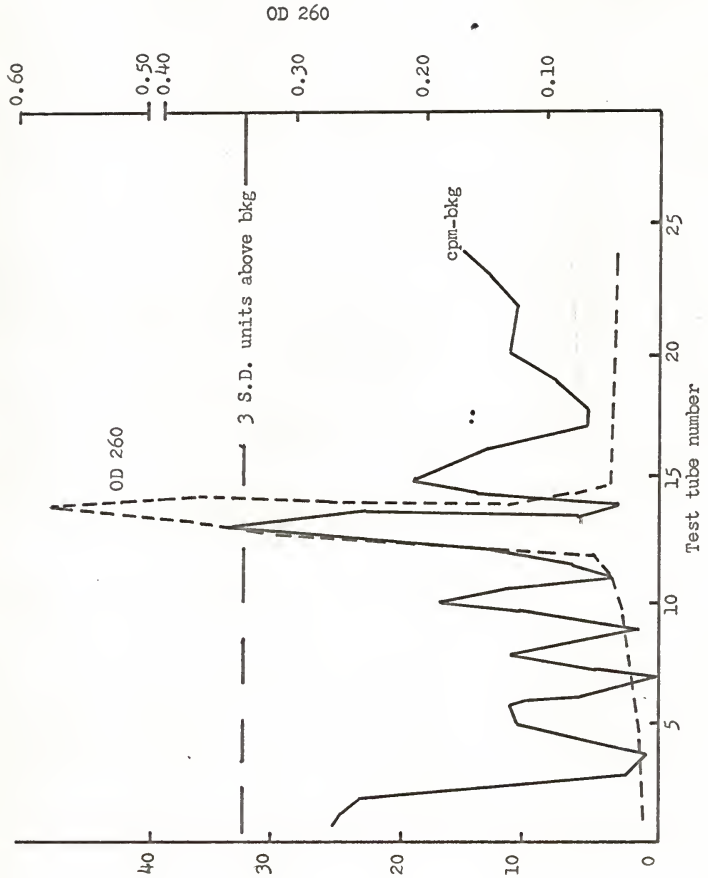

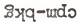




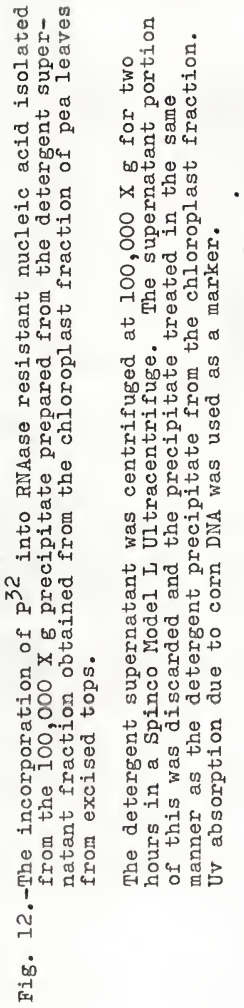


cpm-bkg

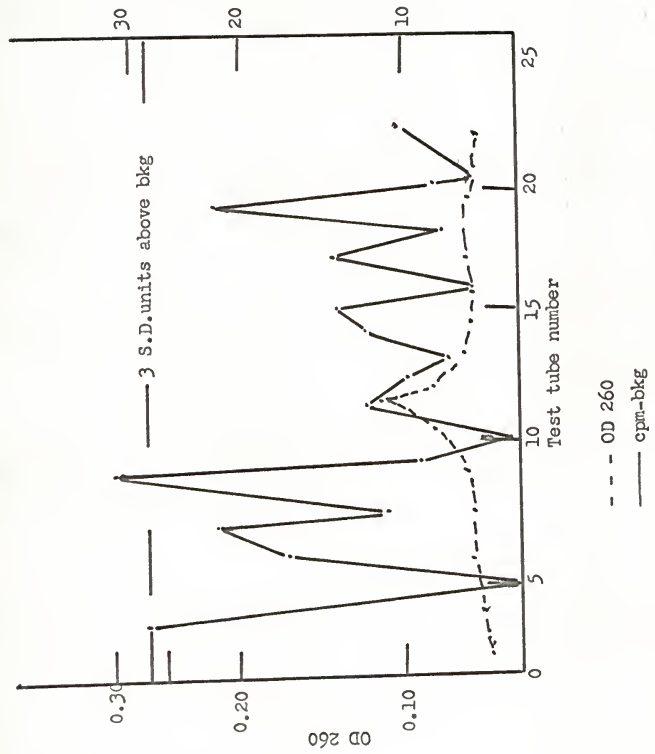


No coincidence of uv absorption maximum and $\mathrm{P} 32$ count maximum was observed in this case. This is in keeping with results found previousiy with colorimetric determinations. The results differ from those results obtained by Brawerman and Eisenstadt (1964), in which they found a DNA in the $100,000 \times \mathrm{g}$ precipitate prepared from the supernatant fraction of detergent treated Euglena chloroplasts.

Previous work with diphenylamine reagent seemed to indicate that the detergent supernatant fraction contained a DNA which was still present in solution after decantation from the $100,000 \mathrm{Xg}$ precipitate. This solution was discarded in the last experiment. These new experiments were designed to check on the presence of DNA in the detergent supernatant fractions. Figures 13 and 14 show that both the chloroplast and mitochondrial detergent supernatant fractions contain DNA. In this case more DNA seems to have been released from the mitochondrial fraction.

In interpreting these experiments, it becomes necessary to show that all of the RNA was degraded by the RNAase treatments. The philosophy behind these experiments is that when nucleic acid is prepared from whole leaves rather than from chloroplast fractions more RNA and DNA are released. If the same amount of enzyme is brought into contact with the larger sample and completely hydrolyzes it at room 


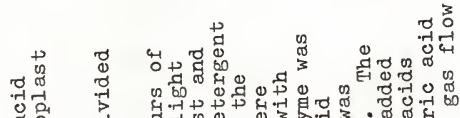

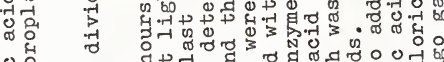

0

म्ने तु

व1

व

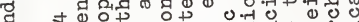
ฟ 0 \&.-1 0 .

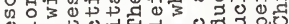

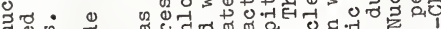

द्व 0 ण $++$

+0 :

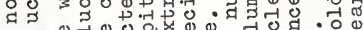

क 4 ग

†े 吹

.

व 0

$0+a_{1}$

4 द

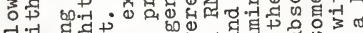

d

(1) 600

(2) 15

तै $0 .+1$

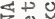

है⿴囗十⿱ 口)

वृद्यु फ्म

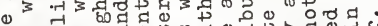

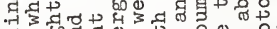

हैंत 0 -

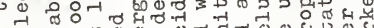

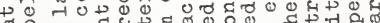
क 0 द्व

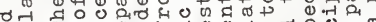

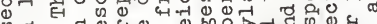

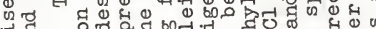
-

$0+v$

त्व

요

त d

- क्ष

$\therefore$ नु द्वै है त्ठ

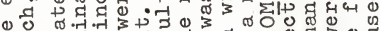

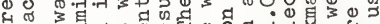
(1) व

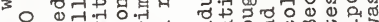

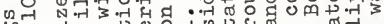
bु नु वृष वृ

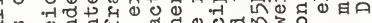

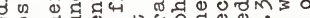

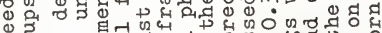
() 几 $\circ$ 年

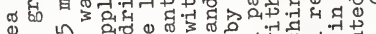

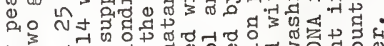
उस द्ञ

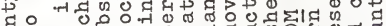

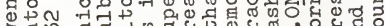

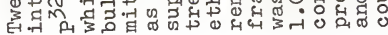
ही वृ क्ष 1

m

bi

㷉 
Total Counts

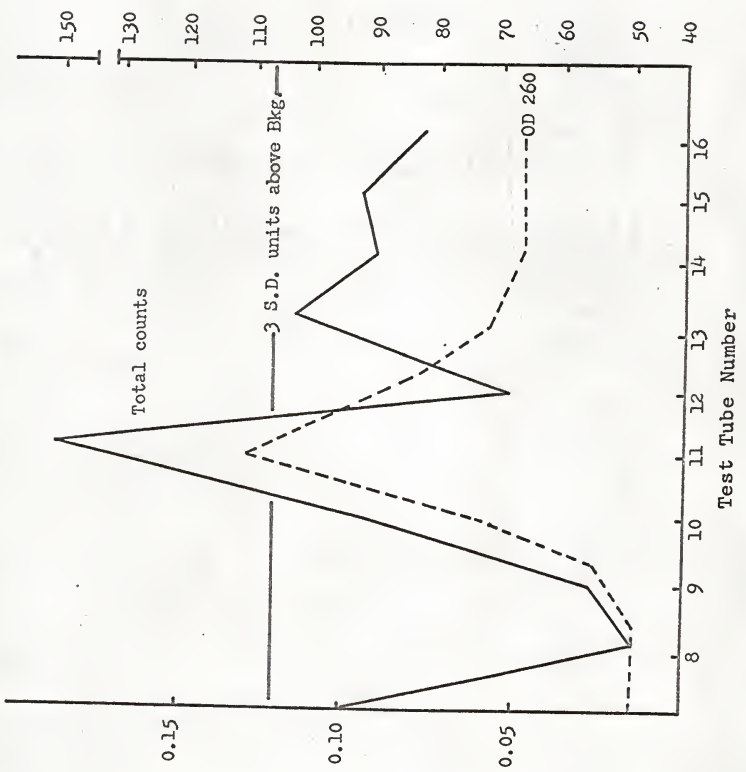




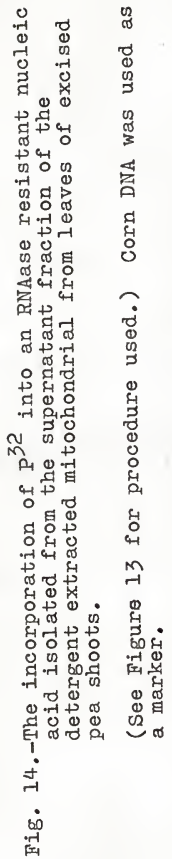




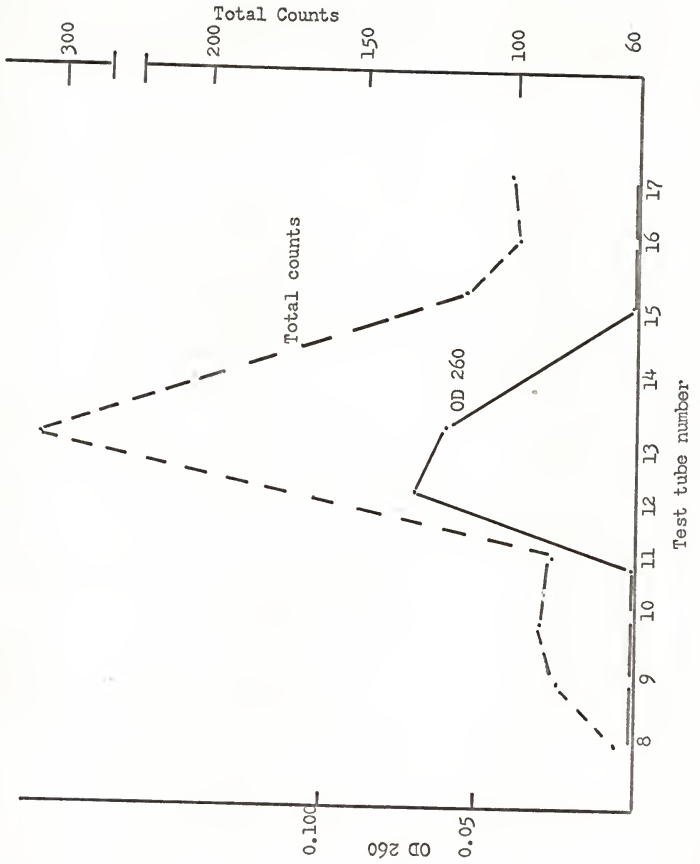


temperature with the same period of exposure which was used for the chloroplast extracts then this digestion procedure is more than adequate to be used in the purification of chloroplast DNA.

Deoxyribosenucleic acid was prepared from whole pea leaves by grinding the leaves in a mortar and pestle with phenol. Large unbroken fragments were re-ground using the same procedure. Deoxyribosenucleic acid was released by this process since long stringy fibers characteristic of the substance were observed upon precipitation with ethanol. The nucleic acids were taken up in $25 \mathrm{ml}$ of saline-citrate and three $5 \mathrm{ml}$ aliquots were taken for tests. In all cases, as shown in Figure 15, the amount of nucleic acids released was quite small; more probably remained present in the undegraded leaf material which was discarded.

To overcome this problem it was decided to use an omni-mixer to facilitate the breakup of the leaves. The nucleic acld suspension was divided into three portions of $3 \mathrm{ml}$ each. One portion was treated for one hour with 100 $\mathrm{ug} / \mathrm{ml}$ RNAase at room temperature. Another sample was treated with $0.3 \mathrm{ml}$ of $1 \mathrm{mg} / \mathrm{ml}$ DNAase for one hour at room temperature. One portion was not treated with nucleases.

Nucleases were removed with bentonite. Each sample was fractionated by passing it through a methylated albumin column using a linear sodium chloride gradient in which $400 \mathrm{ml}$ 


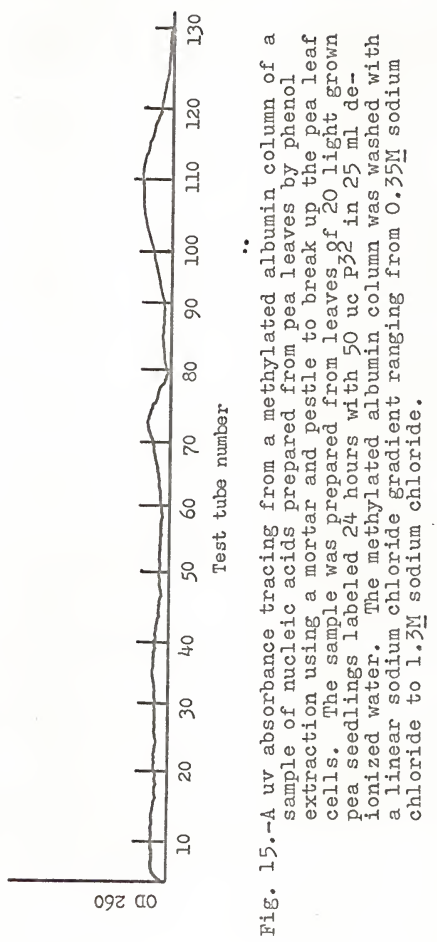


$0.35 \mathrm{M} \mathrm{NaCl}$ was added to the mixing chamber and 1. 3 $\mathrm{M} \mathrm{NaCl}$ was added to the other chamber. The eluate was collected and the test tubes containing the peaks of interest were separated from the others. After reading the contents of the tubes on a Beckman DB spectrophotometer, two ml samples were removed, dried thoroughly, and counted. (Figure 16, 17). Clearly the two nucleases are effective at the concentrations employed in reducing the concentrations of the particular nucleic acid concerned. RNAase effectively reduces the level of counts in the ribosomal RNA peak that no significant number of counts appears at the part of the gradient where ribosomal RNA is eluted normally. The DNAase enzyme apparently leaves some DNA sufficlently polymerized to appear in its usual position. However, the amount of DNA present in the whole leaf must be greater than that in the chloroplast fractions. This level of DNAase should be adequate to depolymerize the DNA contained in the chloroplast fraction.

The presence of some residual RNA in the DNA/RNA peak would also contribute counts not arising from DNA. Messenger RNA associated with DNA would form an RNAase resistant system. The presence of this complex in the experimental material might negate previous results. To test for the 


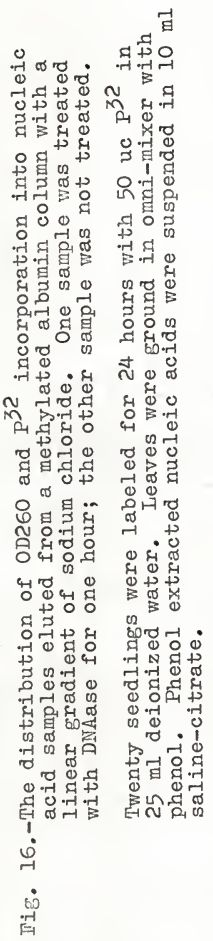




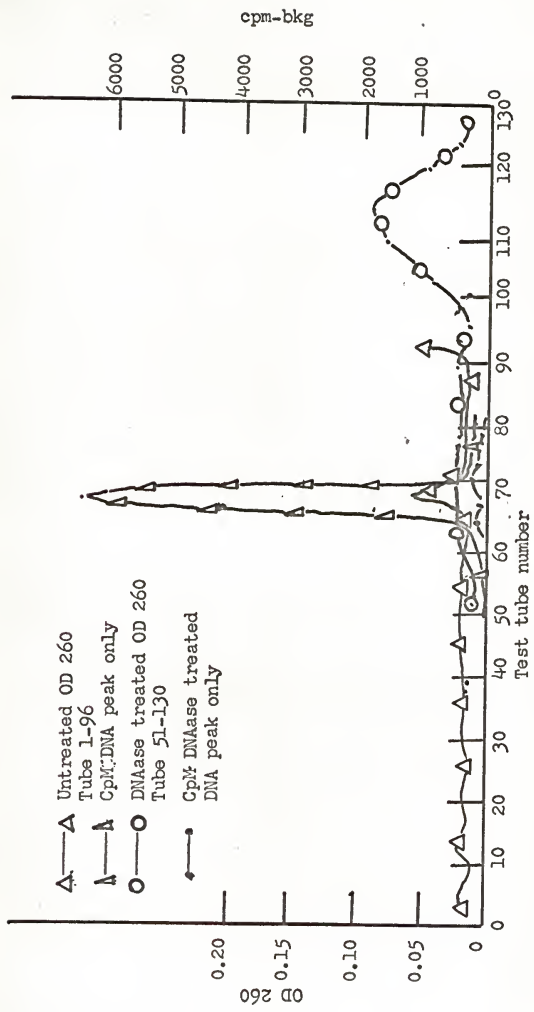




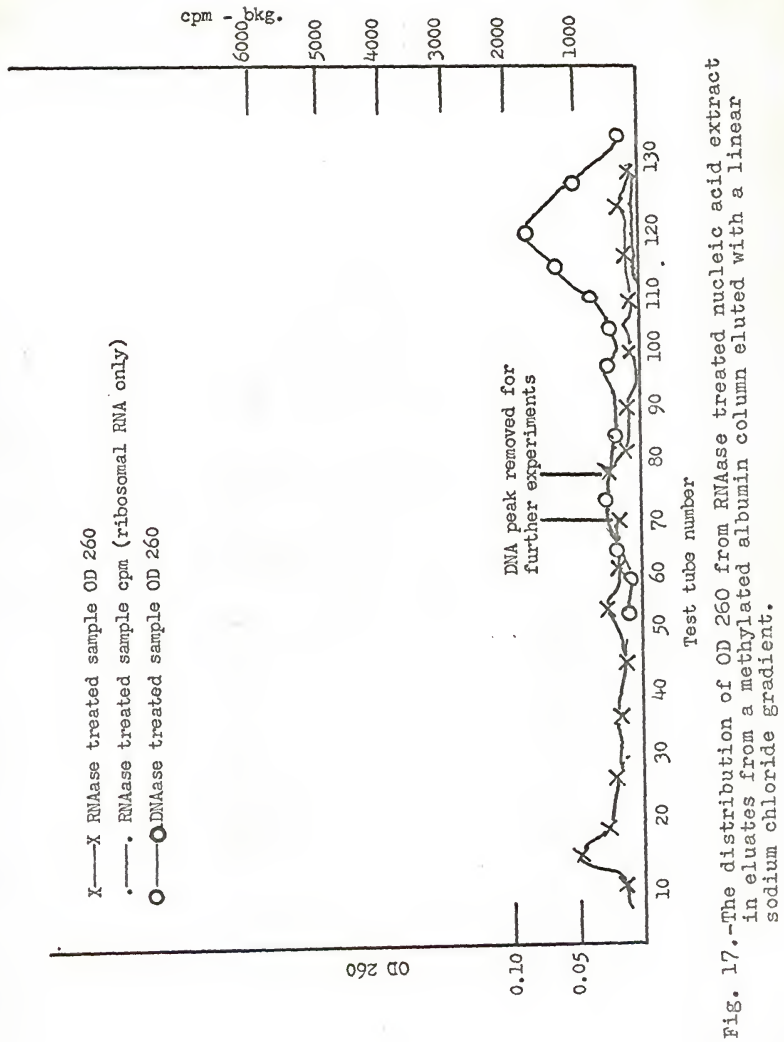


occurrence of this complex, the DNA/RNA peak from the RNAase treated sample was collected and subjected to alkaline hydrolysis. RNA is rendered acid soluble by this procedure. DNA acid insolubility is uneffected. Each collecting tube held $5 \mathrm{ml}$ of eluate. Those tubes containing the major portion of the uv absorbance were selected and a $2 \mathrm{ml}$ aliquot of sample was removed and dried on a planchet. The remaining portion of the eluate was treated with cold IM perchloric acid and subjected to alkaline hydrolysis and all samples were counted at the same time. The results are shown in Table 8. If RNA were attached to DNA the supernatant fraction after basic hydrolysis should have a significant number of counts remaining in it. This was found to be true for several of the fractions. However, these results must be regarded as only preliminary since It is difficult to tell whether the radioactivity is due to RNA or suspended DNA. A comparison between the radioactivity recovered by alkaline extraction and that from the untreated portion of the sample reveals that a large amount of radioactivity was lost during the procedure.

A fresh sample of pea chloroplasts was prepared, and nucleic acids extracted from 1t. Detergent precipitate and detergent supernatant fractions were prepared. All 


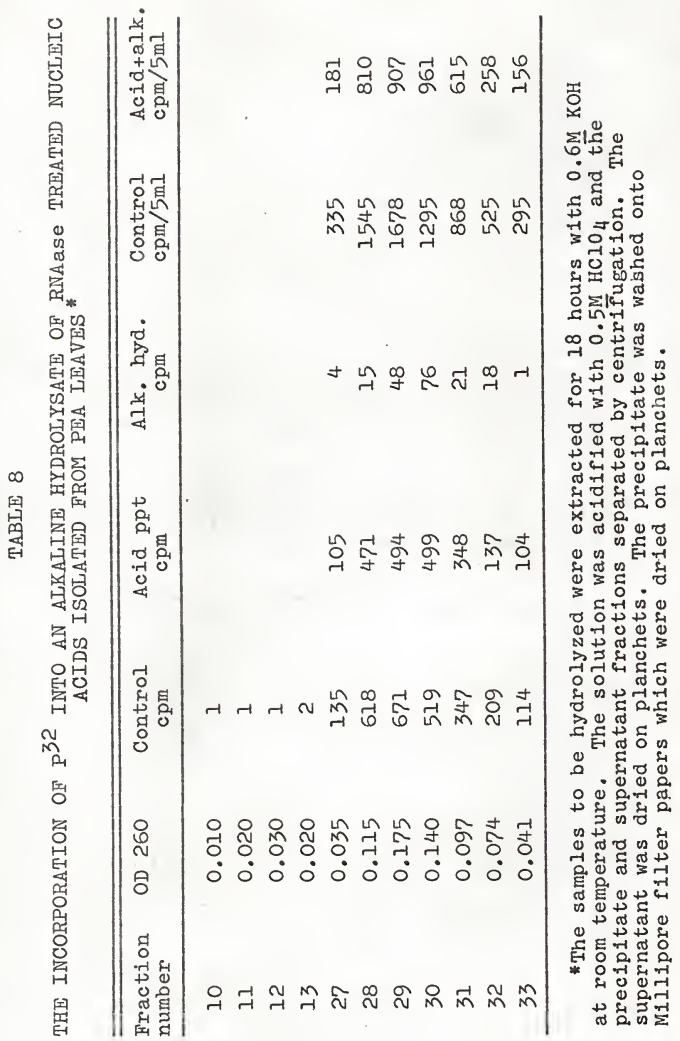


fractions were passed through methylated albumin columns without the addition of a marker DNA. A detectable amount of DNA was not washed off the column by $0.35 \mathrm{M} \mathrm{NaCl}$ but was eluted with the second $50 \mathrm{ml}$ of $1.0 \mathrm{M} \mathrm{NaCl}$. Table 9 shows the results when these washings were read on a DB spectrophotometer. A significant amount of uv absorbance was found in the eluates of the chloroplast detergent precipitate and the mitochondrial supernatant. It was then possible to study the DNA from the isolated chloroplast fractions without adding any other kind of DNA.

The major portion of the uv absorbance eluted from the methylated albumin column in the last experiment was collected and treated with DNAase. Before treatment, one of the samples was passed through the column to see if it would elute at the same position where it appeared on the first passage. As shown in Figure 18 the peak appeared on the same point as before, namely, when the second $50 \mathrm{ml}$ of 1. $0 \mathrm{M} \mathrm{NaCl}$ buffer was added. After treatment with the enzyme, both samples were eluted with $0.35 \mathrm{M} \mathrm{NaCl}$. At the second fifty $\mathrm{ml}$ aliquot of $1.0 \mathrm{M} \mathrm{NaCl}$ virtually no uv absorbance was eluted. If the material was DNA, treatment with this enzyme should give this result.

The procedure for preparation and separation of nucleic acids from chloroplast containing fractions was a bit long. 


\section{TABLE 9}

THE DISTRIBUTION OF UV ABSORBING MATERIAL ${ }^{2}$ IN $1.0 \mathrm{M} \mathrm{NaCl}$ BLUATES FROM A METHYLATED ALBUMIN COIUMN TO WHICH SAMPLES PREPARED FROM DETERGENT EXTRACTED CHLOROPLAST AND MITOCHONDRIAL FRACTIONS WERE ADDEDb

\begin{tabular}{ccccc}
\hline $\begin{array}{l}\text { Test } \\
\text { tube } \\
\text { number }\end{array}$ & $\begin{array}{c}\text { Chloroplast } \\
\text { detergent } \\
\text { precipitate } \\
\text { OD 260 }\end{array}$ & $\begin{array}{c}\text { Chloroplast } \\
\text { detergent } \\
\text { supernatant } \\
\text { fraction } \\
\text { OD 260 }\end{array}$ & $\begin{array}{c}\text { Mitochondria } \\
\text { detergent } \\
\text { precipitate } \\
\text { OD 260 }\end{array}$ & $\begin{array}{l}\text { Mitochondria } \\
\text { detergent } \\
\text { supernatant } \\
\text { fraction } \\
\text { OD 260 }\end{array}$ \\
\hline 1 & 0.025 & 0.035 & 0.035 & 0.030 \\
2 & - & 0.035 & 0.025 & 0.030 \\
3 & - & 0.035 & 0.027 & 0.040 \\
4 & - & 0.075 & 0.025 & 0.035 \\
5 & - & 0.025 & 0.020 & 0.035 \\
6 & 0.030 & - & - & 0.030 \\
7 & - & 0.010 & 0.030 & 0.030 \\
8 & 0.015 & - & - & 0.030 \\
9 & 0.040 & 0.020 & - & 0.045 \\
10 & 0.070 & 0.000 & 0.040 & 0.110 \\
11 & $0.110^{\mathrm{d}}$ & 0.000 & 0.046 & 0.155 \\
12 & $0.100^{\mathrm{d}}$ & 0.000 & 0.054 & 0.125 \\
13 & 0.020 & 0.000 & 0.030 & 0.070 \\
14 & 0.032 & 0.000 & 0.035 & 0.050 \\
15 & 0.020 & 0.000 & 0.020 & 0.035
\end{tabular}


Table 9 (cont'd)

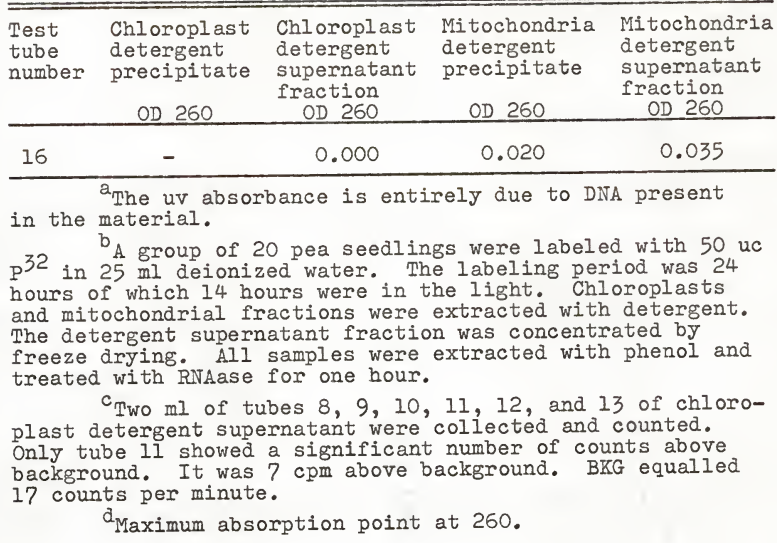




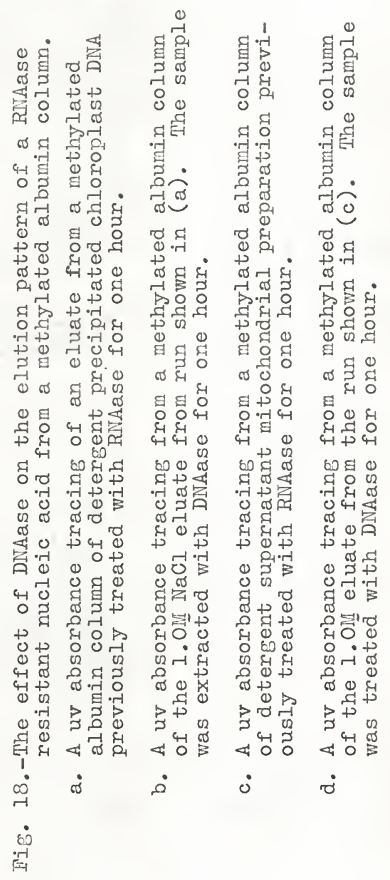



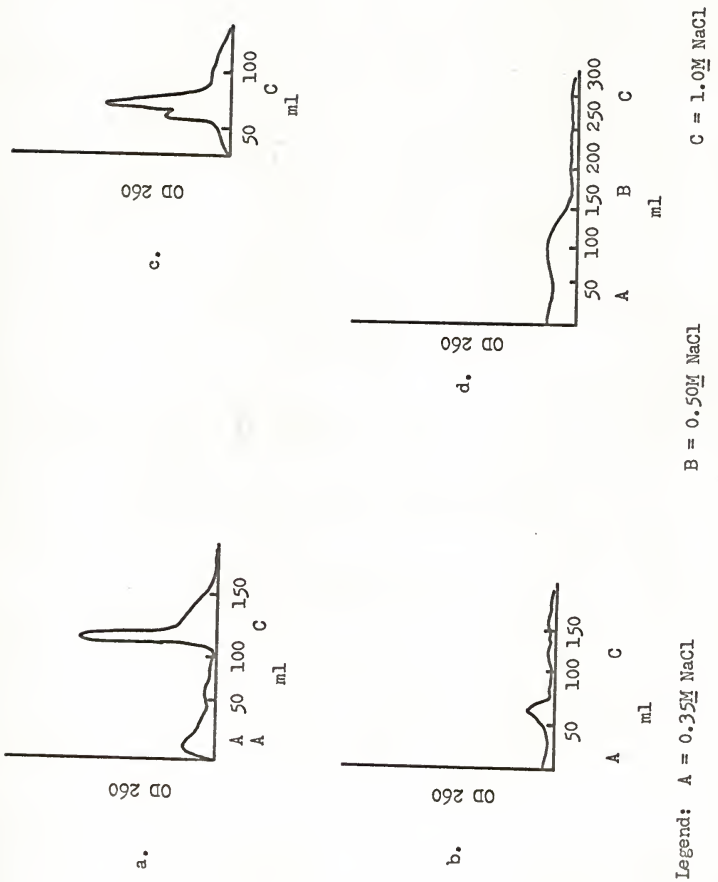
An attempt was made to shorten the process by leaving out the elution of the sample from a methylated albumin column. To remove RNA from DNA an alkaline hydrolysis procedure was used. Since the samples were counted rather than studied by means of their uv absorbances, the presence of a small amount of detergent which absorbs heavily at 260 should not interfere with the determination of the relative amounts of $\mathrm{P}^{32}$ incorporation into DNA. The chloroplast and mitochondrial fractions were prepared and extracted with detergent. The acid precipitates of each fraction were hydrolyzed in alkali and after acidification the supernatant fraction was separated from the precipitate. Both were collected and counted in the usual manner. The results of this experiment are presented in Table 10. More counts were retained in these fractions than were retained by previous techniques. Several explanations are possible for this. The precipitates counted are not only DNA but may contain protein and cell wall material. In adition, in spite of careful washing with lipid solvents some phospholipid may be retained. The presence of phosphoprotein also cannot be ruled out. The light and dark treatment both developed some chlorophyll. The covering over the seedlings supposedly grown in the dark was not sufficlent to exclude all light. The great differences in incorporation between the light and supposedly dark grown samples remained 
TABLE 10

THE INCORPORATION OF $\mathrm{P}^{32}$ INTO ALKALI INSOLUBLE AND SOLUBLE PORTIONS OF DETERGENT EXTRACTED MITOCHONDRIAL AND CHLOROPLAST FRACTIONS** ISOLATED FROM ETIOLATED PEA LEAVES** EXPOSED TO LIGHT AND DARK ****

\begin{tabular}{|c|c|c|}
\hline & $\begin{array}{l}\text { Alkali } \\
\text { insoluble } \\
\text { cpm above } \\
\text { bkg }\end{array}$ & $\begin{array}{l}\text { Alkali } \\
\text { soluble } \\
\text { cpm above } \\
\text { bkg }\end{array}$ \\
\hline \multicolumn{3}{|c|}{ Detergent precipitate } \\
\hline \multicolumn{3}{|l|}{ light treated } \\
\hline $\begin{array}{l}\text { chloroplast } \\
\text { mitochondria }\end{array}$ & $\begin{array}{r}76 \\
441\end{array}$ & $\begin{array}{l}142 \\
720\end{array}$ \\
\hline \multicolumn{3}{|l|}{ dark treated } \\
\hline $\begin{array}{l}\text { chloroplast } \\
\text { mitochondria }\end{array}$ & $\begin{array}{l}133 \\
720\end{array}$ & $\begin{array}{l}190 \\
879\end{array}$ \\
\hline \multicolumn{3}{|c|}{$\begin{array}{l}\text { Detergent supernatant fraction } \\
\text { light treated }\end{array}$} \\
\hline $\begin{array}{l}\text { chloroplast } \\
\text { mitochondria }\end{array}$ & $\begin{array}{r}25 \\
206\end{array}$ & $\begin{array}{r}57 \\
292\end{array}$ \\
\hline \multicolumn{3}{|l|}{ dark treated } \\
\hline $\begin{array}{l}\text { chloroplast } \\
\text { mitochondria }\end{array}$ & $\begin{array}{r}41 \\
141\end{array}$ & $\begin{array}{r}361 \\
87\end{array}$ \\
\hline
\end{tabular}

${ }_{*}^{*} 50$ uc $\mathrm{P}^{32}$ in $25 \mathrm{ml}$ deionized water for 24 hours. * Chloroplast and mitochondrial fractions suspended in $40 \mathrm{ml} 0.01 \mathrm{M}$ Tris buffer $\mathrm{pH} 7.7$ containing $0.01 \mathrm{M} \mathrm{Mg}^{++}$; $0.5 \mathrm{ml}$ of 5 per cent deoxycholate added to the suspension. Centrifuged at $30,000 \mathrm{Xg}$ for one hour. *** Two batches of etiolated seedlings, 20 each, were excised from roots. One batch was exposed to 14 hours of light, the other was grown in the dark under a beaker covered with Al foil placed in the same growth chamber as the light grown seedlings. 
Table 10 (cont'd)

***All fractions were treated with an equal volume of cold $1 \mathrm{M}^{-} \mathrm{HClO}_{4}$ and the acid precipitates extracted with absolute ethanol. Alkaline hydrolysis was for 18 hours at room temperature using $0.6 \mathrm{M} \mathrm{KOH}$. The hydrolysate was acidified and the precipitate separated from the supernatant by means of a $30,000 \mathrm{x} \mathrm{g}$ centrifugation. The supernatant fraction was dried in stainless steel planchets. The precipitate was washed into planchets with acetone and dried. 
unexplained since both apparently got enough light to begin the manufacture of chlorophyll. These results cannot be simply explained by differences in light intensity even though the shaded samples must have had less intense light than the light-grown samples. The determination of the amount of chlorophyll synthesized in the samples would have been an aid in resolving this question. Protein also should have been determined because the size of the samples might have been quite different. The larger incorporation of isotope into the mitochondrial fraction is explainable by assuming that the chloroplasts have not reached their most mature stage of development. The developing chloroplasts are usually less massive than the mature chloroplasts, hence it takes a higher centrifugal force to sediment the younger plastids.

It was interesting to compare the $\mathrm{P}^{32}$ incorporation of plants growing under darkened conditions and those starting to green. To determine if the greening procedure involved a synthesis of chloroplast DNA, two groups of seedlings were grown, one exposed to light for six hours and the other in total darkness. The 3,000 $\mathrm{x} g$ centrifugation was omitted since few plastids from etiolated plants would sediment at this speed. The $30,000 \mathrm{x} g$ precipitate was extracted with detergent after the usual sucrose gradient 
centrifugation. Methylated albumin chromatography was performed after phenol extraction and RNAase digestion. Only the 1.OM eluate was collected for counting. Both light and dark treated samples were counted at the same time. The samples were approximately the same size. The data in Table 11 indicate that there was little difference in the incorporation of $\mathrm{P}^{32}$ into the chloroplast precipitate. The distribution of radioactivity is probably not significant since this depends on many uncontrolled factors.

The detergent supernatant fractions were not concentrated on a freeze dryer or extracted with RNAase. Instead, the entire $100 \mathrm{ml}$ of the sample was placed on a methylated albumin column which was washed with the buffer suspending the nucleic acids. Although the supernatant fraction was buffered at $\mathrm{pH} 7.7$ and the column is ordinarily run at $\mathrm{pH} 6.7$ the change in $\mathrm{pH}$ did not seem to affect the retentative ability of the column since the second fifty $\mathrm{ml}$ of $1.0 \mathrm{M} \mathrm{NaCl}$ also eluted the major portion of the uv absorbing material as usual. As shown in Figure 19, similar peaks occurred in extracts from both light and dark grown plants. The two supernatants were mixed together and treated with DNAase for one and one-half hour. The results, shown in part (c) of Figure 19, demonstrated that both DNA and RNA were present in the samples. The DNA was elutable 
by a low ionic strength buffer $(0.35 \mathrm{M} \mathrm{NaCl}$ leaving a uv absorbance peak still attached to the column. This peak must be either a RNA or an unhydrolyzed DNA. Previous experiments with DNAase indicated that this enzyme seldom left appreciable amounts of DNA undegraded. The presence of RNA in extracts from chloroplasts isolated from darkgrown plants was reported earlier in Table $I$ and Figure 3. The methylated albumin column may also be used to concentrate nucleic acid suspensions when the material is suspended in large volumes of liquid.

CHARACTERIZATION OF THE DNA ISOLATED

CsCl gradient centrifugation. The central problem remaining was the identity of the DNA fractions prepared by the detergent treatments. Were the DNAs isolated from the detergent precipitate and from the detergent supernatant the same or different molecules? To answer this question two approaches were undertaken.

Different species of DNAs may be separated by density gradient centrifugation. CsCl solutions may be prepared which approximate the density of most DNA molecules. Such solutions when centrifuged rapidly for a day at constant temperature have established in them a concentration of gradient. Foreign molecules will distribute themselves in the gradient according to their buoyant densities. A relationship exists between the buoyant density of the 
TABLE 11

INCORPORATION OF $\mathrm{P}^{32 *}$ INTO THE DETERGENT PRECIPITATES** ISOLATED FROM THE $30,000 \mathrm{X}$ g PRECIPITATE PREPARED FROM LEAVES OF ETIOLATED PEA PIANTS*** EXPOSED TO SIX HOURS OF IIGHT OR TO DARKNESS

\begin{tabular}{ccc}
\hline $\begin{array}{l}\text { Fraction from } \\
\text { methylated } \\
\text { albumin column }\end{array}$ & $\begin{array}{c}\text { Dark grown } \\
\text { plants } \\
\text { cpm above bkg }\end{array}$ & $\begin{array}{c}\text { Iight grown } \\
\text { plants } \\
\text { cpm above bkg }\end{array}$ \\
\hline 9 & 2 & 4 \\
10 & 8 & 3 \\
11 & $11(\mathrm{~s})$ & 2 \\
12 & 7 & $11(\mathrm{~s})$ \\
13 & 1 & 4
\end{tabular}

* Iabeled with 30 uc $\mathrm{p}^{32}$ in $25 \mathrm{ml}$ deionized water for 26 hours.

** The $30,000 \mathrm{X} \mathrm{g}$ precipitate was suspended in $100 \mathrm{ml}$ of Tris buffer containing $0.01 \mathrm{M} \mathrm{Mg}^{++}$. Ten $\mathrm{ml} 5$ per cent sodium deoxycholate was added and the suspension was centrifuged for one-half hour at $30,000 \mathrm{X} g$. Phenol extraction, alcohol precipitation and methylated albumin chromatography were performed. The 1.OM NaCl eluates were collected and counted.

*** The leaves were homogenized in a Brendler homogenizer. 
molecule and its base composition. Using this technique it is possible to separate two species of DNA and calculate the base composition of each. (Vinograd and Hearst 1962). Another method of characterizing DNA requires molecules of a single species to be present. Contaminants effect the results in unforseen ways. DNA is a double stranded molecule whose two complimentary parts are held together by hydrogen bonds existing between purines and pyrimidines in different strands. One pair, the guanine - cytosine $(G-C)$ pair has one more hydrogen bond than the adenine - thymine pair. Heating solutions of the molecule cause the unfolding of the strands - the so called melting phenomenon. Molecules containing higher guanine - cytosine contents than other molecules will have higher melting point ranges than molecules of lower G-C content. The mid-point of the melting point range is taken as a convenient measure of this range. Marmur and Dotty (1962) used a large number of bacterial DNAs to derive a relationship between melting temperature and base composition.

CsCl gradient centrifugation

A sample of E. coll DNA was added to the top of a preformed $\mathrm{CsCl}$ gradient. The sample was centrifuged for 12 hours at $120,000 \mathrm{Xg}$ at $19^{\circ}$. At the end of this time 


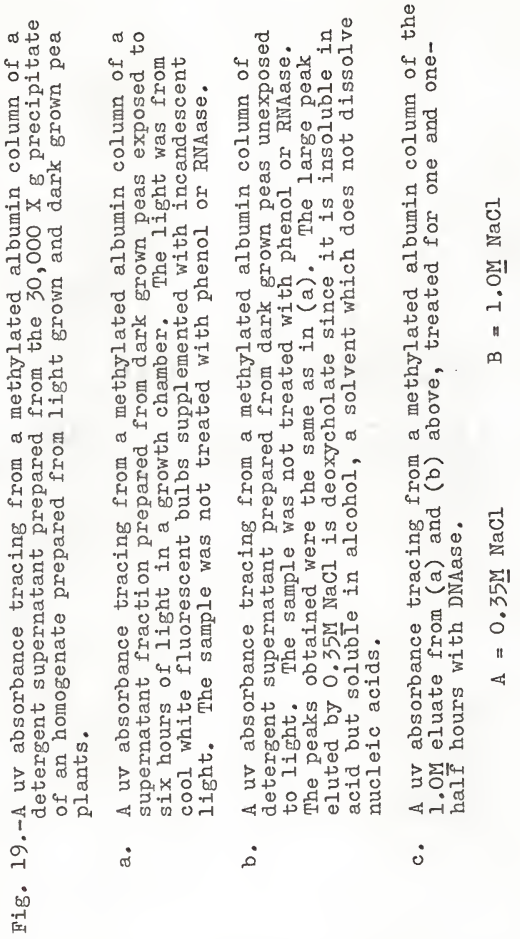



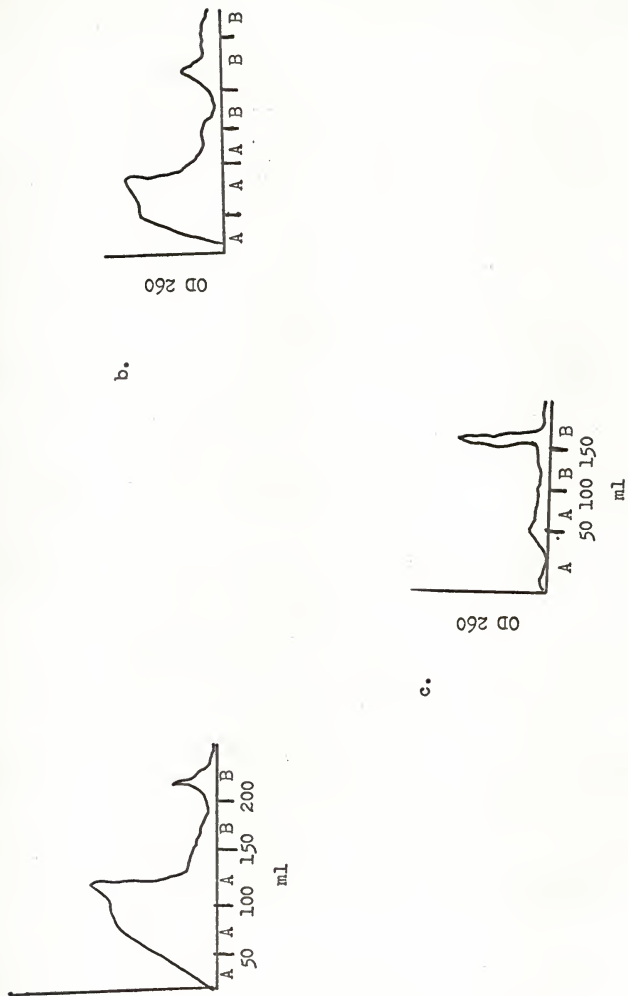

092 do 
the sample was divided into equal parts and read on a Beckman DB spectrophotometer fitted with a microcuvette. The results of this experiment are shown in Table 12. E. coli DNA bands at one particular spot in the gradient. The density of the solution at this point is close to the buoyant density of $\underline{E}$. coli DNA, 1.710, reported by Schildkraut, Marmur, and Dotty (1962). E. coli DNA was used in these preliminary experiments because its buoyant density is known. The position of $\mathrm{E}$. coli DNA in the gradient would form a spot of known density from which assuming linearity of gradient it would be possible to calculate densities of other molecules. Other experiments were done using pea and oat DNAs but the results were inconclusive.

The long periods of centrifugation at high speed and the difficulties in handling the easily disturbed density gradients made this technique less advantagous than the apparently simpler melting point procedure. Since a technique had already been worked out for the purification of the chloroplasts, fairly pure chloroplast DNA should be obtained. The melting point procedure was adopted as the chief means of characterizing the DNA. 
TABLE 12

THE DISTRIBUTION OF OPTICAL DENSITY AT $260 \mathrm{mu}$ DUE TO E. coli DNA THROUGH A CSCl GRADIENT

\begin{tabular}{|c|c|c|c|}
\hline $\begin{array}{l}\text { Sample } \\
\text { number }\end{array}$ & OD 260 & $\begin{array}{l}\text { Pt. max. } \\
\text { absorbance }\end{array}$ & Buoyant density* \\
\hline 27 & 0.250 & & \\
\hline 26 & 0.195 & & \\
\hline 25 & 0.315 & 270 & \\
\hline 24 & 0.205 & plateau 270 & \\
\hline 23 & 0.195 & plateau 270 & \\
\hline 22 & 0.200 & plateau 270 & \\
\hline 21 & 0.230 & plateau 270 & \\
\hline 20 & 0.270 & plateau 270 & \\
\hline 19 & 0.290 & plateau 270 & \\
\hline 18 & 0.269 & plateau 270 & \\
\hline 17 & 0.241 & plateau 270 & \\
\hline 16 & 0.195 & plateau 240-260 & \\
\hline 15 & 0.290 & plateau 240-260 & \\
\hline 14 & 0.285 & plateau 240-260 & \\
\hline 13 & 0.270 & plateau 240-260 & \\
\hline 12 & lost & - & \\
\hline 11 & 0.358 & - & 1.6318 \\
\hline 10 & lost & - & - \\
\hline 9 & 1.00 & 260 & 1.6970 \\
\hline 8 & 0.340 & no peak 260 & - \\
\hline 7 & 0.270 & no peak 260 & 1.6318 \\
\hline 6 & 0.319 & no peak 260 & 1.6839 \\
\hline 5 & 0.229 & no peak 260 & 1.6025 \\
\hline 4 & 0.250 & no peak 260 & 1.5834 \\
\hline 3 & 0.248 & no peak 260 & 1.5840 \\
\hline
\end{tabular}


Table 12 (cont'd)

\begin{tabular}{cccc}
\hline $\begin{array}{c}\text { Sample } \\
\text { number }\end{array}$ & OD 260 & $\begin{array}{l}\text { Pt. max. } \\
\text { absorbance }\end{array}$ & Buoyant density* \\
\hline 2 & 0.248 & $\begin{array}{c}\text { no absorbance } \\
\text { at } 260\end{array}$ & 1.5775 \\
1 & 0.240 & $\begin{array}{c}\text { no absorbance } \\
\text { at } 260\end{array}$ & 1.5645 \\
\hline
\end{tabular}

The buoyant density of certain fractions was calculated by measuring the index of refraction of the fraction in a refractometer.

* A CsCl gradient was prepared using a gradient maker. Three $\mathrm{ml}$ of a $\mathrm{CSCl}$ solution of buoyant density 1.800 were added to the cylinder containing the effluent valve. Three $\mathrm{ml}$ of a $\mathrm{CsCl}$ solution of buoyant density 1.600 were added to the other cylinder. After the gradient was formed, two $\mathrm{ml}$ of $\mathrm{CsCl}$ solution of buoyant density 1.800 were added to the very bottom of the gradient to prevent the sample from binding in the hemispherical portion of the tube. Two ml of CsCl solution of density 1.600 were added to top of gradient. The solution contained E. coli DNA. The gradient was centrifuged at $120,000 \mathrm{Xg}$ for 12 hours at $19^{\circ} \mathrm{C}$ in head 50 of the Spinco Model L preparative ultracentrifuge. At the end of this time, the tube containing the gradient had a hole punched in its bottom with a tube punching apparatus and five drops of the gradients were collected into each collecting tube. The OD 260 of each tube was read on a Beckman DB spectrophotometer against a water blank. A microcuvette with an effective volume of $0.3 \mathrm{ml}$ and a light path of $0.1 \mathrm{~cm}$ was used to read the samples. 


\section{Melting Point Determinations}

Deoxyribosenucleic acidsisolated from whole pea leaves and from the mitochondrial and chloroplast fractions were heated in a cuvette in a Beckman DU spectrophotometer. The temperature of the chamber was raised to about $75^{\circ} \mathrm{C}$. Each temperature regime was maintained for about ten minutes. At the end of this time the control on the thermoregulator of the circulating water bath was rotated to give a rise within the cuvette of approximately $2^{\circ} \mathrm{F}$. OD readings were expressed as relative increase in optical density (RIOD) obtained by dividing the optical density reading at a temperature by one obtained at a standard temperature usually room temperature. The data obtained were plotted on a curve as in Figures 20 and 21 . In Figure 21 the curves are not plotted against the same RIOD values in each curve. The RIOD values have been so chosen to minimize the distances of the lowest RIOD value from the $x$ axis. This procedure was adopted in calculating the midpoint of the melting point profile curves. The increase in optical density observed occurs over approximately the same range of temperature. This suggests that the same molecule is involved in the denaturation. Variation in relative increase in optical density was due to variations in the reading at the standard temperature which sometimes was higher in value than the readings at 
Fig. 20.-Melting point profiles of pea DNAs.

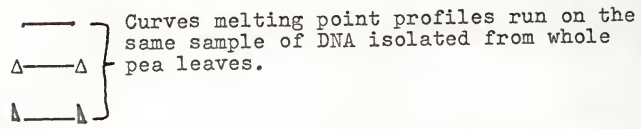

- - - A melting point profile run on a sample of DNA isolated from chloroplast fraction from pea leaves prepared 9/14.

$\multimap$ A melting point profile run on a sample of DNA prepared from the chloroplast fraction isolated from pea leaves $9 / 15$. 


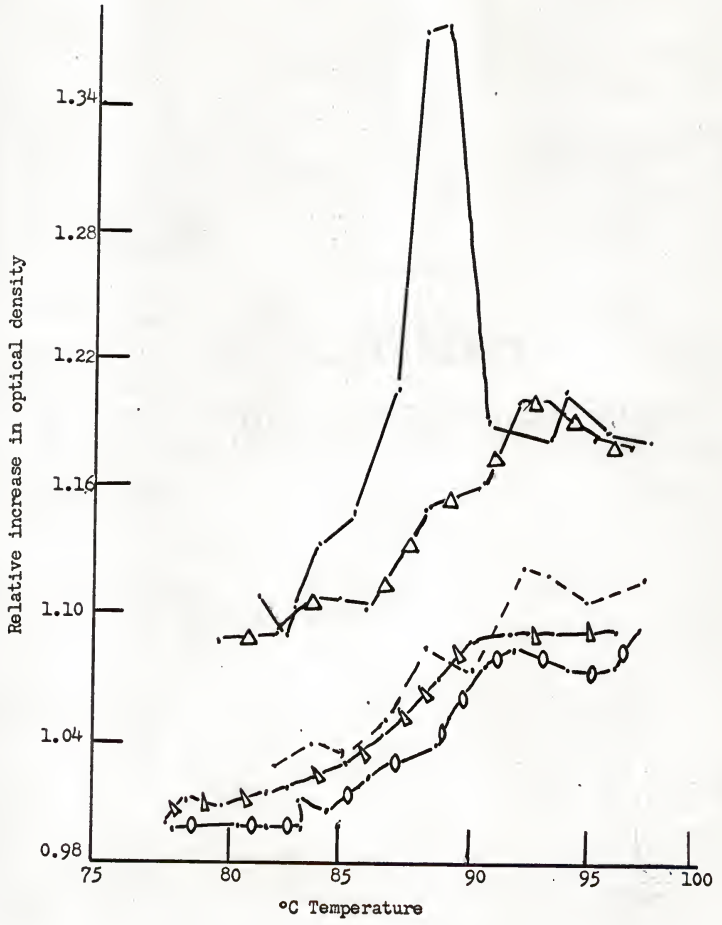




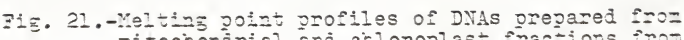
mitochonürial ana chloroplast fractions irou pea leaves.

Curve 1 - Chloroplast fraction $8 / 4 \quad \Delta-\Delta$

Curve 2 - Mitochondrial fraction $8 / 5$

first experiment

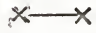

Curve 3 - Chloroplast fraction 9/14 - - -

Curve 4 - Mitochondrial fraction $8 / 5$

second experiment

Curve 5 - Mitochondrial fraction 8/11

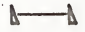

Curve 6 - Chloroplast fraction 9/15

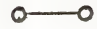




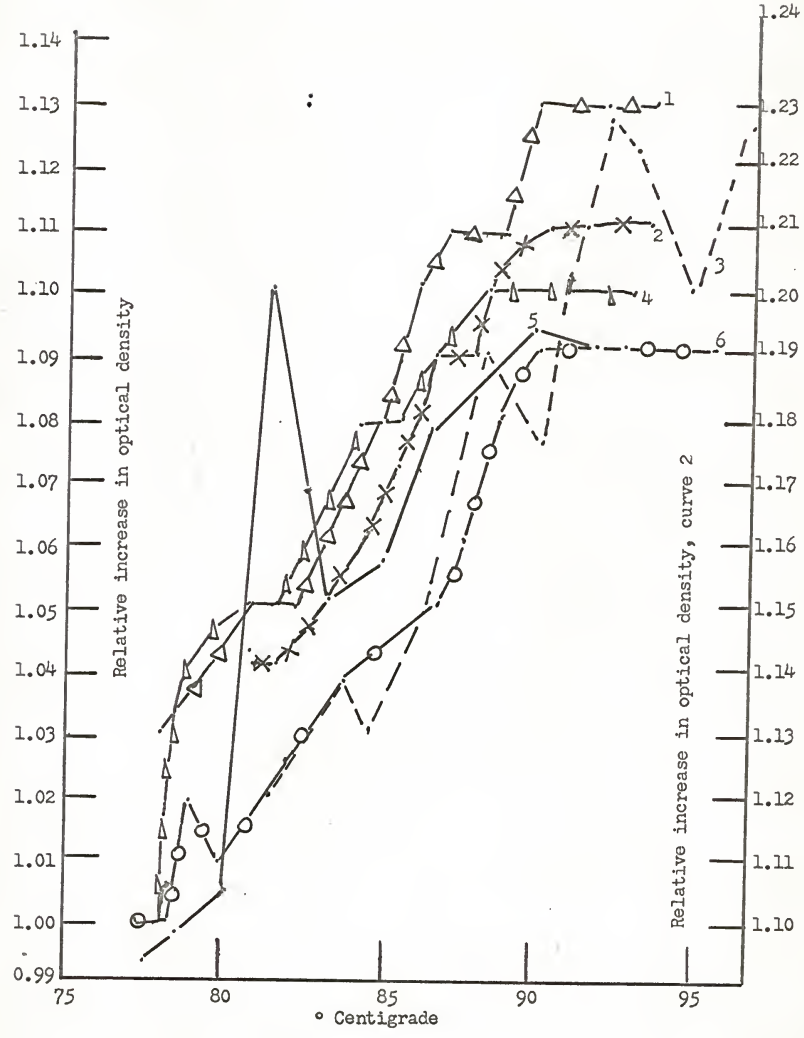


higher temperatures. This led to fractional values for RIOD. These could not be plotted on the same paper as the majority of other values without assigning these low values to the same axis and plotting the points using these values. This procedure led to the discovery that in spite of the variations in RIOD values the curves often resembled each other in form.

In calculating the midpoint of the denaturation curve the following assumptions were made:

a. The same DNA is present in both mitochondrial and chloroplast fractions.

b. The melting point curves for this DNA are sigmoid in nature and resemble those given by Marmur and Dotty (1962) for E. coli DNA.

c. A single curve could be fitted to the points making up the five curves of Figure 21. The middle portion of this curve would be approximated by a straight line. The points between the temperatures $81^{\circ} \mathrm{C}$ and $88^{\circ} \mathrm{C}$ were chosen because they are most likely to lie on the linear portion of the curve as inferred from the experimental results. A straight line was fitted to these points by the method of least squares. The midpoint of the melting point curve could be estimated by taking the point of the line segment between the two linear horizontal portions of the melting point profile. The datawere plotted so that the 
lowest value would be the $\mathrm{x}$ axis. The upper value was calculated by calculating the average value of $y$ at the three highest temperatures, values which were clearly in the horizontal portion of the curve. The melting point of the DNAs isolated from the mitochondrial and chloroplast portion was $84.8^{\circ} \mathrm{C}$ and corresponds to a GC composition of 37.76 mole per cent.

In Figure 20, curves 1, 2, and 5 are curves drawn from the same sample of DNA isolated from whole pea leaves. Curves 3 and 4 are melting point curves of chloroplast fraction DNA isolated from pea. The melting point range of the curves were approximately the same suggesting that they are the same molecule. Hence the DNA base composition cited above must be indicative of pea nuclear DNA. 


\section{DISCUSSION}

Deoxyribosenucleic acid was demonstrated to be present in chloroplast and mitochondrial fractions from pea leaves. The demonstration depended upon the removal of all uv absorbing substances other than DNA. Deoxyribosenucleic acid was detected by its resistance to RNAase treatment, its position of elution on a methylated albumin column, its uv absorption spectrum and most of all by its depolymerization upon treatment with DNAase.

Deoxyribosenucleic acid from homogenates of plant cells may arise from several sources other than chloroplasts. Some of these are the nucleus, the mitochondria, and chance microbiological contaminations. It is necessary to show that the DNA isolated from an homogenate differs in base composition from nuclear DNA of the same plant. Microbiological contaminations would be harder to rule out because of the difficulties of establishing an aseptic culture of large plants. Most microblological populations on the surfaces of healthy plant leaves are small and this possible source of contamination is, therefore, unlikely to be detected. Mitochondria are difficult to separate from plastids broken during the isolation procedure. For this reason it is difficult to interpret results 
showing a different base composition than nuclear in mitochondria containing fractions. Edelman, Schiff, and Epstein (1965) reported the presence of DNA in the mitochondria of Fuglena. They found that it was necessary to utilize radioisotopic technique to locate the mitochondrial DNA since it was present in such small quantities. The chloroplast DNA was detected by optical means. The detectability of the mitochondrial DNA by optical means depends on using enough material. Since optical methods for the most part were used in the detection of plastid DNA, the possibility of mitochondrial DNA contamination is a minor one. Phosphorus count incorporation would undoubtedly not distinguish between the two forms.

In order to prepare pure chloroplast DNA some method would have to be used to separate the DNA species from each other. Methylated albumin chromatography, so useful in the separation of RNA species and RNA and DNA is not useful for this purpose as shown by the close coincidence of $\mathrm{P}^{32}$ counts incorporated into pea DNA and the OD 260 peaks of corn DNA. $\mathrm{CsCl}$ gradient centrifugation makes it possible to separate the mitochondrial, chloroplast and nuclear DNA.

Another possible way to demonstrate the presence of different DNAs in the same cell is the calculation of the melting point of isolated DNA from melting point profiles run under standard conditions. The DNA melting point calcu- 
lated from extracts of whole leaves would be characteristic of nuclear DNA since this is the species of DNA present in the highest quantity in cells. Isolation and purification of chloroplast fractions would reduce the amount of nuclear DNA in the fraction and change the calculated melting point to one more characteristic of chloroplast DNA.

A method discovered by Brawerman and Eisenstadt (1964) can be used for separating the nuclear DNA from chloroplast DNA without using $\mathrm{CsCl}$ gradient centrifugation. The chloroplast fraction was extracted with sodium deoxycholate. The bounding membranes of the chloroplast disintegrate under this treatment as can be seen when detergent is added to plastid suspensions under the microscope. The internal membranes of the photosynthetic lamella system are unaffected by this treatment since most of the chlorophyll which is membrane bound is sedimentable at $30,000 \mathrm{Xg}$. A DNA was sedimented along with these plastid fragments. It had a base composition differing from nuclear DNA and appeared at the same buoyant density level in a $\mathrm{CsCl}$ gradient to which chloroplast DNA was sedimented in previous experiments. A DNA of base composition resembling the nuclear one was recovered from the supernatant by a 100,000 X 8 centrifugation. Apparently the internal membranes of the plastid prevent the release of the chloroplast DNA to the supernatant. Somewhat similar results were reported by Iwanmura (1960). Chlorella 
cells were exploded by placing them in a French press under high pressure and suddenly releasing the pressure. The external membranes of the plastid were destroyed by this procedure but a DNA was recoverable from the plastid fragments sedimenting at $20,000 \mathrm{X} \mathrm{g}$. When the supernatant was sedimented at $105,000 \mathrm{Xg}$ a DNA of different base composition was found. Iwanmura concluded that the DNA associated with the plastid fragments was chloroplast DNA and that found in the supernatant fraction was nuclear DNA. Ris and Plaut (1962) observed that the DNAase sensitive areas in the sections chloroplasts of Chlymydomonas observed under the electron microscope were completely surrounded by the internal lamella of the plastid. Recently Bezinger, Molchanov, and Sissakin (1966) observed that a nucleic acid was associated with the isolated lamella system of kidney bean chloroplasts. These results indicate that the chloroplast DNA must be somehow associated with the lamella system of the plastids. It is then possible to prepare bounding membraneless plastids which still retain their DNA. The evidence is also good that the nuclear particles are much less stable to these treatments and rapidly lose their material to the external medium. Stable nuclei are exceedingly difficult to prepare.

Both the detergent extracted plastid and mitichondrial fractions show DNA in the supernatant portion and in the 
precipitate. Although a DNA does not sediment when the detergent supernatant fraction of peas is sedimented at $100,000 \mathrm{X} g$ as is the case in Euglena, evidence would suggest that a similar situation occurs in the detergent extraction of pea chloroplasts. Further characterization of the DNA associated with the two fractions would have to be made before a final decision could be made.

A slight amount of $\mathrm{P}^{32}$ was incorporated into the plastids during the 24-hour labeling period. This indicates that chloroplast DNA synthesis is proceeding. It is unknown whether the plastid division continues with cessation of cell division in a mature plant cell. In the rapidly elongating internodal cell of Nitella (Green, 1964), chloroplast division still proceeds after cell division has stopped. No evidence was found on this point. 


\section{SUMMARY}

Deoxyribosenucleic acid was isolated from chloroplast containing cell-free fractions prepared from pea leaves. The DNA was freed from protein and lipid by a phenol extraction procedure. Ribosenucleic acid was removed by hydrolysis with RNAase and passage through a methylated albumin column. The hydrolyzed RNA was washed off the column with low ionic strength buffers. The unhydrolyzed DNA remained on the column and was eluted by buffers of higher ionic strength. The DNA was depolymerized by treatment with DNAase. The major portion of the DNA liberated and isolated by the fractionation procedures occurred in the chloroplast containing fractions. On treating the isolated fractions with 5 per cent sodium deoxycholate, a portion of the DNA was not sedimented with the chloroplast fragments. It was found in the supernatant fraction and was not sedimented by a 2-hour centrifugation at $100,000 \mathrm{X} g$. Another portion of the DNA was sedimentable with the plastids after detergent treatment. Attempts to characterize these different fractions were not successful.

A small amount of $\mathrm{P}^{32}$ was incorporated into the DNA of the chloroplast containing fractions. This was only a small portion of the total $\mathrm{P}^{32}$ incorporated into the DNA of the leaves. 


\section{BIBIIOGRAPHY}

Arnon, D.I. 1949. Copper enzymes in isolated chloroplasts. Polyphenol oxidase in Beta vulgaris. Plant Physiol. 24:
l - 15.

Balthus, E. and J. Brachet. 1963. Presence of DNA in chloroplasts of Acetabularia mediterranes. Biophy. et Biochim. Acta. 76: $490-492$.

Bezinger, E.N., M.I. Molchanov, and N.M. Sissakin. 1966. Dokl. Akad. Nauk. SSSR 166: 738 - 741. Chem. abs. 1966. 64 : $11456 \mathrm{~h}$.

Brawerman, G. and J.M. Eisenstadt. 19E4. Deoxyribosenucleic acid from chloroplasts of Euglena gracilis. Biophy. et Biochim. Acta. 91: 477 - 485 .

Brendler, H. 1951. A simple inexpensive microhomogenizer. Science. 114: 61-- 62 .

Burton, K. 1956. A study of the conditions and mechanisms of the diphenjlamine reaction for the colorimetric estimation of DNA. Biochem. J. 62: 315.

Chiba, Y. and H. Sugahara. 1957. Nucleic acid content of chloroplasts. Arch. Biochem. Biophy. 71: $367-376$.

Qchun, E.H.I., M.H. Vaughan and A. Rich. 1963. The isolation and characterization of DNA associated with chloroplast preparations. J. Mol. Biol. 7: 130 - 141 .

Edelman, M., J.A. Schiff and E.T. Epstein. 1965. Studies of chloroplast development in Euglens, XII. Two types of satellite DNA. J. Mol. Biol. 11: $760-768$.

Fisher, W.D., G.B. Cline and N.G. Anderson. 1964. Density gradient centrifugation in angle head rotors. Anal. Biochem. 9: 477 - 482 .

Gibor, A. and S. Granick. 1964. Plastids and mitochondria: inheritable systems. Science. 1945: 890 - 896.

Gibor, A. and M. Izawa. 1963. The DNA content of chloroplasts of Acetabularia. Proc. Nat. Acad. Sci. 50: 1164 1168. 
Granick, S. 1955. Plastid structure, development and inheritance. Encyclopedia of plant physiol. W. Ruhland edit. Springler-Verlag, Berlin. 1: $507-564 \mathrm{p}$.

Green, P.B. 1964. Cinematic observation on the growth and division of chloroplast in Nitella. Amer. J. Bot. 51: 334 - 342 .

Iwanmura, T. 1960. The distribution of nucleic acids among subcellular fractions in Chlorella. Biochim. et Biophys. Acta. 61: $472-\frac{174}{474}$

Kirk, J.T.0. 1963. The deoxyribosenucleic acid content of broad bean chloroplasts. Biochem. J. 88 (supl.): 45 p.

( ) Lowry, N.J. 1957. Method of protein determination, in Method of Enzymol. Vol. III. Acad. Press, New York 448 - $449 \cdot \mathrm{p}$.

Mandell, J.D. and A.D. Hershey. 1960. A fractionating column for analysis of nucleic acids. Analy. Biochem. $1: 66$.

Marmur, J. and P. Dotty. 1962. Determination of base composition of DNA from their denaturation temperatures. J. Mol. Biol. 5: 109 - 118 .

Marmur, J. 1961. A procedure for the isolation of DNA from microorganisms. J. Mol. Biol. 3: $208-218$.

Ogur, M. and G. Rosen. 1950. The nucleic acids of plant tissue. I. The extraction and estimation of deoxypentosenucleic acid. Arch. Biochem. 25: $262-27 \overline{6}$.

Ray, D.S. and P.C. Hanawatt. 1965. Satellite DNA in Euglena cell chloroplasts. J. Mol. Biol. 11: $760-768$.

Ris, E. and W. Plaut. 1962. The ultrastructure of DNA containing areas of the chloroplasts of Chlamydomonas. J. Cell Biol. 13: $383-385$.

Sagan, I.Y. Ben-Shaul, H.T. Epstein, and J.A. Schiff. 1965. Studies of chloroplast development in Euglena. XI. Radioautographic localization of chloroplast DNA. Plant Physiol. 40: 1257 - 1260.

Sager, R. and M.R. Ishida. 1963. Chloroplast DNA in Chlamydomonas. Proced. Nat. Acad. Sci. U.S. 50: 725 - 
Salo, T. 1965. A simple tube puncturing device for use with density gradient centrifugation. Analy. Biochem.
$10: 344$.

() Sch1ldkraut, C. L., J. Marmur and P. Dotty. 1962. Determination of the base composition of DNA from its buoyant density in CsCl. J. Mol. B101. 4: $430-443$.

Shipp, W. S., F. J. Kieras and R. Haselkorn. 1965. DNA assoclated with tobacco chloroplasts. Proc. Nat. Acad. Sc1. U.S. 54: $207-213$.

Smillie, R. M., W. R. Evans and H. Lyman. 1963. Metaboletic events during the formation of a photosynthetic from a non-photosynthetic cell, in meristems and differentiation. Brookhaven Symposium in Biology 16: 89 - 108.

Stocking, C. R. and E. M. Gifford. 1959. Incorporation of thymidine into chloroplasts of Spirogyra. Biophys. and Blochem. Res. Commun. 1: 59.

Vinograd, J. and J. E. Hearst. 1962. Equilibrium sedimentation of macromolecules and viruses in a density gradient. Fortschr. Chem. Org. Naturestoffe. 20:395.

Walker, D. A. 1965. Correlation between photosynthetic activity and membrane integrity in isolated pea chloroplasts. Plant Physiol. 40: 1157 - 1161.

Wollgiehn, R. and K. Mothes. 1964. Uber die Incorporation von 3 H-Thymidin in die Chloroplasten-DNS von Nicotiana rustica. Expt. Cel Res. 35: $52-57$. 


\section{BIOGRAPHICAI SKETCH}

Ernest Wilson was born at Jamaica, New York, October 9, 1938. He completed his secondary education at New York, New York in June, 1956. He received his Bachelor of Science degree with a major in biology from Queens College, Flushing, New York, June, 1960. He received his Master of Science degree in botany from the University of Maryland in September, 1962. 
This dissertation was prepared under the direction of the chairman of the candidate's supervisory committee and has been approved by all members of that committee. It was submitted to the Dean of the College of Agriculture and to the Graduate Council, and was approved as partial fulfillment of the requirements for the degree of Doctor of Philosophy.

August 13, 1966

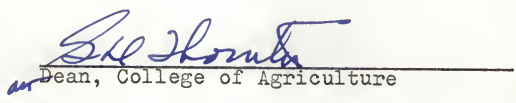

Dean, Graduate School

Supervisory Committee:

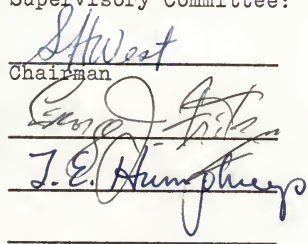

m. Wilen 